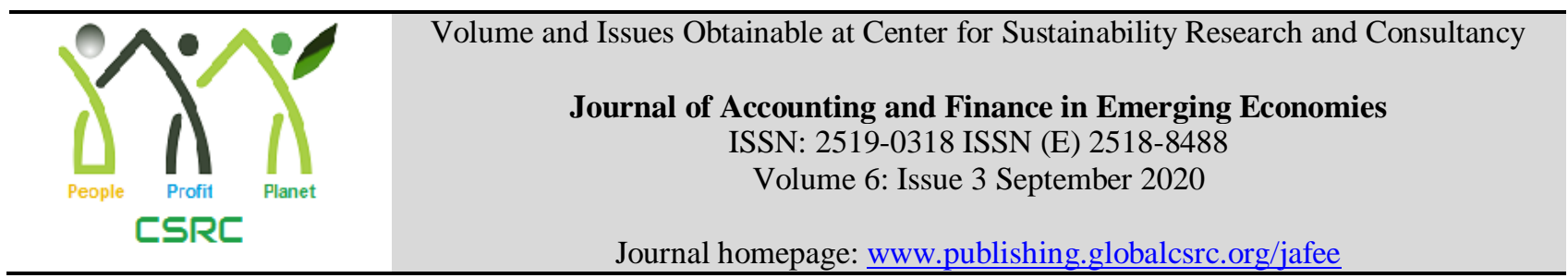

\title{
Reflection of Regulatory Announcement in Equity Market: Fresh Insight from Oil \& Gas Sector of Pakistan
}

\begin{tabular}{l}
\hline ARTICLE DETAILS \\
\hline History \\
Revised format: August 2020 \\
Available Online: September \\
2020 \\
\hline Keywords \\
Regulations, oil and gas \\
regulatory authority (OGRA), \\
Stock market, Event study \\
methodology \\
\hline
\end{tabular}

JEL Classification

G1, G14, L5, L25
This study is based on the problem that how regulations made by oil and gas regulatory authority influences the companies in oil and gas sector of Pakistan. We identify 13 regulatory changes in oil and sector of Pakistan which broadly includes the announcement related to the formulation, functions and responsibilities of oil and gas authority, deregulation and changes in the prices of oil and gas products, interference of apex court into the oil and gas sector and privatization of oil refineries in emerging market of Pakistan. Well-liked event study methodology is used to uncover the impact of regulation announcement on equity prices in Pakistan. Beside this, we also capture the effect of regulation announcement on the firm performance by introducing the dummy variable in ordinary least framework. In line with the financial and econometric theory criteria, we use the sales growth, leverage, liquidity and tangibility as control variables. Study reveal that regulatory announcements have statistically significant aggregate effect on the oil and gas sector of Pakistan stock exchange. We recommend to the policy makers, managers and regulators that the stock prices of oil and gas companies are more sensitive toward the regulatory announcements related to interference of Supreme Court and regulations concerning to the formulation, functions and responsibilities of oil and gas regulatory authority in Pakistan.

\section{OPEN ACCESS}

(C) 2020 The authors, under a Creative Commons Attribution-NonCommercial 4.0

Corresponding author's email address: waris.ali@ uosahiwal.edu.pk

Recommended citation: Husnain, M., Islam, K. \& Ali, W. (2020). Reflection of Regulatory Announcement in Equity Market: Fresh Insight from Oil \& Gas Sector of Pakistan. Journal of Accounting and Finance in Emerging Economies, 6(3), 799-820

\section{Introduction}

The stable and sustainable supply of energy is life blood to socioeconomic development (Su et al., 2017). Fossil fuels such as coal, oil, and gas remain the primary sources used to fulfill the energy requirements of humankind during the last two centuries (Husain, 2010). Oil is the leading fuel in today's technologically advanced world. This is due to its unique attributes - accessibility, versatility, ease of transport, sufficiency, and in many areas, it results cheapest alternative. It accounts for 33\% of global energy consumption (BP Statistical Review of World Energy, 2016) and the weight of oil market in portfolio of global commodity investment is 31\% (Energy Information Administration - EIA, 2016). As per the staff report of US commodity futures trading commission (CFTC), total value of commodity related instruments is increased from 15 billion in 2003 to 200 billion in 2008. Due to this financialization of commodity 
market, oil becomes an essential ingredient in world economy (Tang \& Xiong, 2012; Liu, Wang, Wu \& Wu, 2016; Cheng \& Xiong, 2013).

The fluctuations in oil prices have essential impact on the economic output, unemployment, financial markets, inflation, commodity prices, and all the fundamental industries of the modern industrialized world (Wang \& Zhang, 2014; Wei, Wu, Fan \& Liu, 2008; Du, Yanan \& Wei, 2010; Wang, Wu \& Yang, 2014; Cong, Wei \& Jiao, 2008; Jiao, Gan \& Wei, 2012; Coleman, 2012; Karali \& Ramirez, 2014; Kilian and Park, 2009; Chen, 2015; Wang, Wu \& Yang, 2013). A plethora of literature supports the implication of fluctuations in oil prices for government policies, national and international organizations, economists, policy makers and market participant in developed and developing countries. Since oil is a commodity product therefore its prices also depend upon the supply, demand and speculations in derivative markets (Liu et al., 2016; Wei \& Zhou, 2010). Besides this, price of any security can be represented as the present value of all expected future cash flows. Therefore, prices of securities depend upon the expected cash flows and the discount rate. Any factor that affect the steam of cash flows or discount rate, ultimately affect the price of that particular security.

Believers of asset pricing theories argue that return on any security is related to battery of drivers. Arbitrage pricing theory (Ross, 1976) is considered as one of the prime theories in modern asset pricing framework. Followers of arbitrage pricing theory assume that security's return linearly depends upon finite series of drivers. It may be global factors, institutional factors, other non-economic factors, economic factors, industry specific factors, and other firm specific characteristics. In addition, literature on standard finance firmly advocates the informational efficiency of financial markets, primarily proposed by Fama (1970). The semi-strong form of efficient market hypothesis suggests that current prices fully incorporate all the publicly available information, and therefore no one can earn abnormal profits. Public information not only limited to past prices, but also includes the information reported in a company's financial statements (annual reports, income statements, filings for the security and exchange commission, etc.), earnings and

dividend announcements, announced merger plans, the financial situation of company's competitors, expectations regarding macroeconomic factors (such as inflation, unemployment), industry specific regulations, and policies for specific sector of economy.

A plethora of literature support the argument that oil prices heavily influenced by series of factors. Therefore, oil prices can be forecasted on the basis of economic growth, changes in expectations of economic growth, global industrial production, liquidity, global interest rate, changes in non-OPEC (The organization of petroleum exporting countries) production, changes in Saudi Arabia crude oil production, supply, demand, legislations related to oil market, political unrest, production, financial markets, weather, speculative buying, and exchange value of the dollar (Bodenstein, Guerrieri \& Kilian, 2012; Belke, Bordon \& Hendricks, 2010; Stock \& Watson, 2002; Mumtaz \& Surico, 2009; Abdallah \& Lastrapes, 2013; Bihan \& Matheron, 2012; Juvenal \& Petrella, 2014; Sims, 2002; Forni \& Gambetti, 2010; Bernanke, Boivin \& Eliasz, 2005; Dave, Dressler \& Zhang, 2013; Boivin, Giannoni \& Mihov, 2009; Beckmann, Belke \& Czudaj, 2014). Figure 1 plots the movements in West Texas intermediate (WTI) crude oil prices (real 2010 dollars). It shows that oil prices can be forecasted on the basis of battery of geopolitical and economic events. Our prime focus of this study is on the reflection of industry specific factors - regulations in oil and gas sector

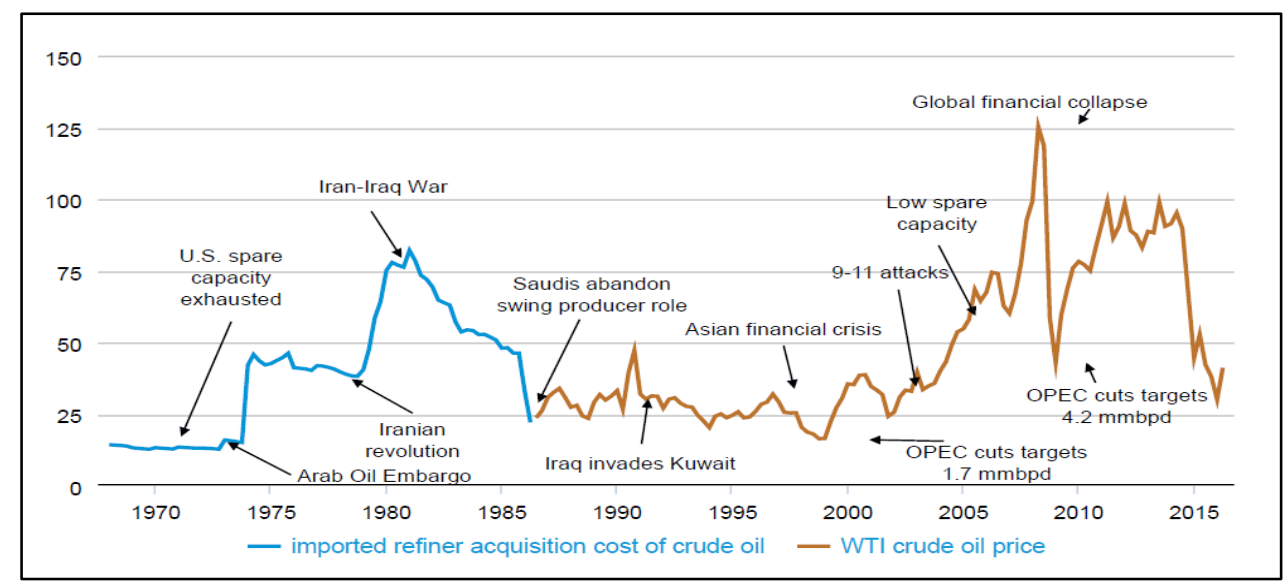

- in the oil prices. 


\section{Figure 1: Variety of drives of crude oil prices Source: U.S. Energy Information Administration, Thomson Reuters}

Regulation can be defined as a rule or directive made and maintained by an authority. It is one of the dimensions of institutional environment and comes under the head of semi-strong form efficient market - publicly available information. General objective of regulation is to improve the transparency of decision making and to depoliticize the tariff settings. But Li and Ferreira (2011) argue that regulations create uncertainties for firms and act as hurdle in firm's operations. If regulations are not properly communicated to firms then it may bring additional cost for producer of goods and services. Literature is too extensive to survey here, but it supports the argument that equity market reflects the regulation announcement (Amin, 2009; McKenzie \& Woodruff, 2013; Kaplan, Piedra \& Seira, 2011; Bruhn, 2013; Monteiro \& Assunção, 2012; Dreher \& Gassebner, 2013).

Pakistani economy is growing at a steady rate that demands relatively higher energy consumptions. Pakistan uses the oil, natural gas and hydro as basic energy resources. The share of oil and gas sector in Pakistani equity market is 17.57\% (Pakistan stock exchange, 2017). Pakistani government had very strict control in the oil and gas sector until 1999. Later on, in April 2006 oil and gas regulatory authority (OGRA) started to notify the price fixation in the sector. Since its inception, OGRA made many changes in regulation to regulate the oil and gas sector. Regulations are central to policy making but excessive and unnecessary regulation are harmful to the economy (Kalyvas \& Mamatzakis, 2014). This study is based on the problem that how regulations made by oil and gas regulatory authority influences the performance of the company in the oil and gas sector of Pakistan. With this motive, we analyses the reflection of regulation announcement in oil and gas sector of equity market of emerging country.

The objective of this study is to investigate the impact of regulation announcement on the listed companies in oil and gas sector of Pakistan stock exchange. We identify 13 regulatory changes in oil and sector of Pakistan. The selected regulation broadly includes the announcement related to the formulation, functions and responsibilities of oil and gas authority, deregulation and changes in the prices of oil and gas products, interference of apex court into the oil and gas sector and privatization of oil refineries in emerging market of Pakistan. Well-liked event study methodology is used to uncover the impact of regulation announcement on equity prices of oil and gas sector. Beside this, we also capture the effect of regulation announcement on the firm performance by introducing the dummy variable in ordinary least framework. In line with the financial and econometric theory criteria, we use the sales growth, leverage, liquidity and tangibility as control variables.

Our finding shows that the events related to formulation, functions and responsibilities of oil and gas regulatory authority has statistically significant impact on the stock prices in both the pre-event and post-event window. We observer a rigorous aggregate effect of oil and gas regulatory authority's ordinance promulgated in both the pre-event and post-event window of cumulative average abnormal returns. The formulation of committee for proposing changes in oil prices by the Supreme Court on November 24, 2009 has statistically significant aggregate impact on the preevent and post-event window of cumulative average abnormal returns in oil and gas sector of Pakistan. We find mixed evidence of response of stock prices of oil and gas companies against the announcement of regulation related to deregulation and changes in the prices of oil and gas products in Pakistan. We recommend to the policy makers, managers and regulators that the stock prices of oil and gas companies are more sensitive toward the regulatory announcement related to interference of Supreme Court and regulations concerning to the formulation, functions and responsibilities of oil and gas regulatory authority in Pakistan.

The rest of paper is organized as follows; next section includes the description of oil and gas sector in Pakistan, the primary energy statistics and consumption of oil in Pakistan. Section 3 presents the literature review which is followed by data description and research methodology. Then, section 4 includes the empirical findings and finally we have brief conclusion of study.

\section{Oil and Gas Sector in Pakistan}

Oil and gas sector in Pakistan is regulated under the petroleum \& natural resources division which was created in April 1977. Oil and gas sector comprise of two main sectors at Pakistan stock exchange (PSE), namely, oil and gas exploration companies and oil and gas marketing companies. There are 4 listed companies in oil and gas marketing sector with a total market capitalization of 1,299,952,502,099 PKR whereas 8 companies are listed in oil and gas 
marketing sector with a total market capitalization of 391,650,223,380 PKR (Pakistan stock exchange, January 2017). According to Facts global energy (2016) report, Pakistani import of crude oil increase by $12 \%$ from year 2014 to year 2015. In 2011, the production of petroleum related product in Pakistan is 70,000 barrels per day that is far below than the production of petroleum products of 95,000 barrels per day in 2015 (International energy agency, 2016). This increase in production is mostly due to the continuous discoveries and ongoing oil exploration projects in Pakistan. Further international monetary fund also document that current government reforms and decline in international oil prices also support the Pakistani oil and gas sector to get rid-off from energy blackouts. Currently, Pakistan has 9 billion barrels of petroleum oil reserves (EIA, 2016). There are six oil refineries in Pakistan with 390,000 barrel per day oil distillation capacity. As per the EIA (2016), Pakistan has 431,000 barrel per day oil consumptions that is mainly in power sector and transportation sector of the country.

Figure 2 shows the decomposition of energy supply of Pakistan into nuclear, hydro, solid, gas and liquid in 2013. Pakistan mainly fulfills its energy requirements from the natural gas, hydro and oil related products. Anyhow, country has great potential in the field of nuclear and hydro related energy products.

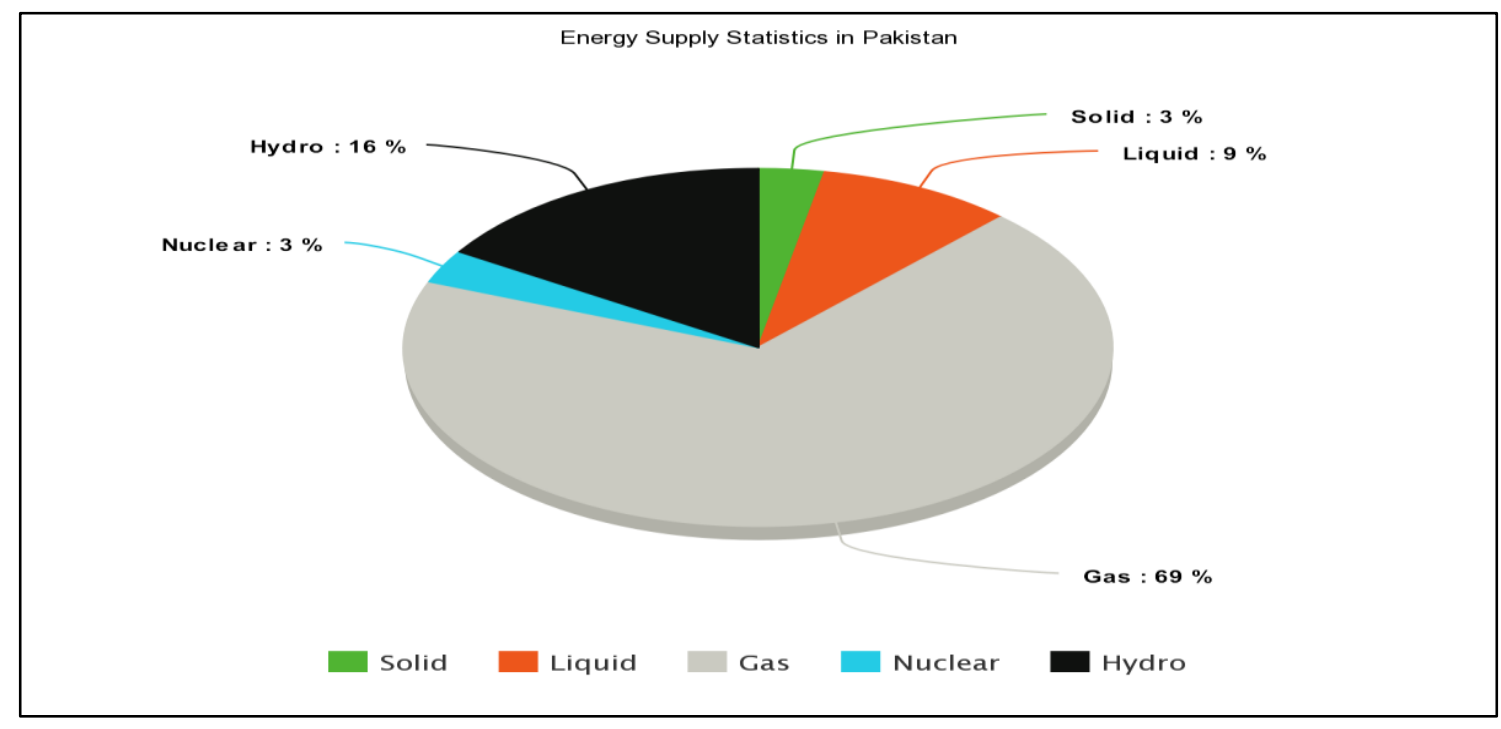

Figure 2: Primary Energy Statistics in Pakistan Source: The International Atomic Energy Agency (IAEA) 
The dominate company in oil and gas in Pakistan is oil and gas development company limited, controlled by government of Pakistan. Beside this, British petroleum and Eni are considered the major overseas companies working

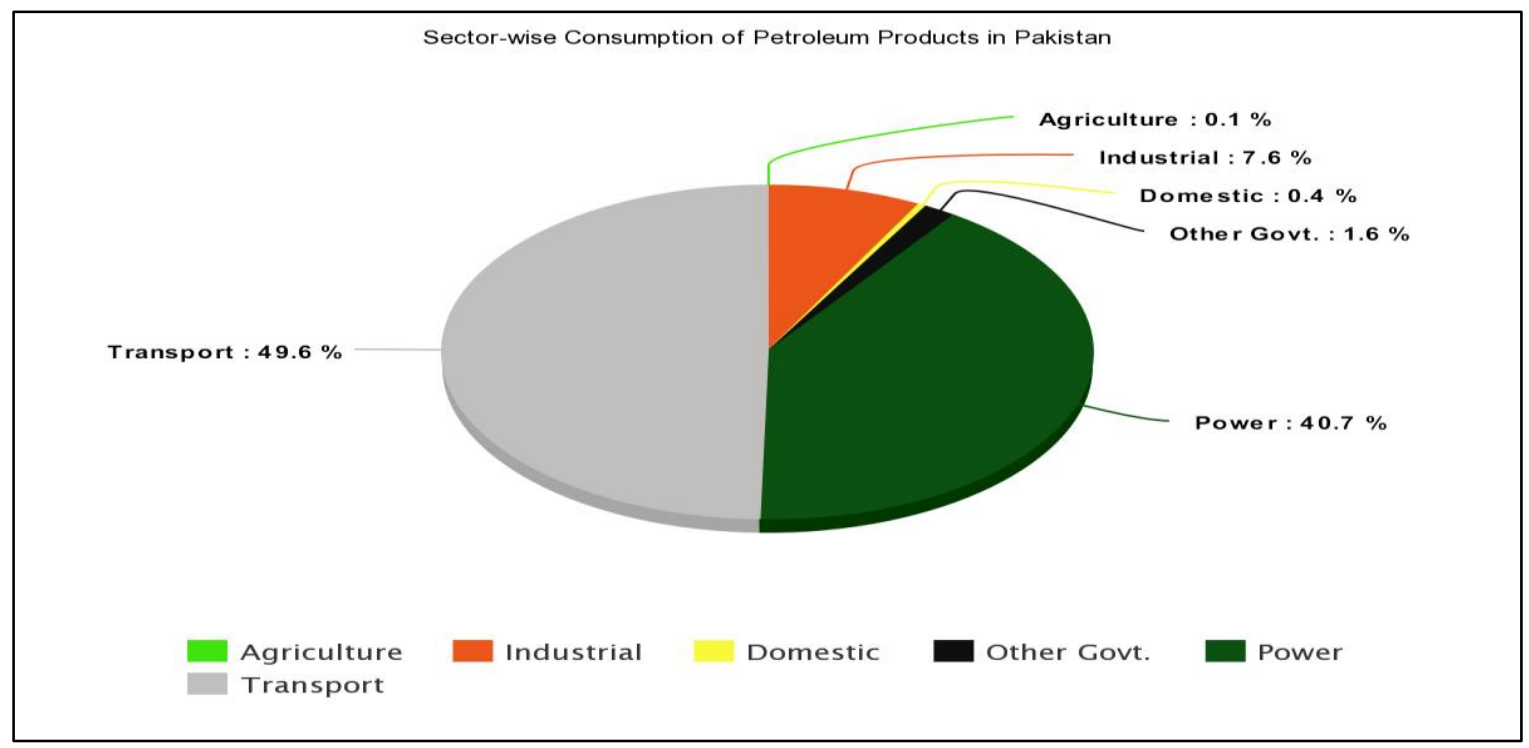

in Pakistani oil and gas sector. Pakistan oilfields consider the market leader in the oil and gas exploration at Pakistan stock exchange. Pakistan finds its first gas field in 152 at Sui gas field. Currently, Pakistan has 105 trillion cubic feet reserve of gas (EIA, 2013). Presently, China showed it deep interest to build gas pipelines that will also connect to Iran under the umbrella of the China-Pakistan economic corridor. Figure 3 shows the sector wise consumptions of petroleum products in Pakistan. It clearly depicts that transportation sector consumes largest portion of petroleum products in Pakistan. Almost $90 \%$ of total petroleum products are consumed in transportation and power sector of the country.

\section{Figure 3: Sector-wise consumption of petroleum products in Pakistan Source: Pakistan Bureau of Statistics (PBS)}

\section{Literature Review}

Regulation is one of the dimensions of institutional environment. It creates uncertainties for firms and act as hurdle in firm's operations ( $\mathrm{Li} \&$ Ferreira, 2011). Regulation is a primary requirement for an industry, and it is made for providing the maximum benefit to both economy and business Stigler's. The Chinese stock market performs different as compare to all other stock market just due to heavy regulations (Bo et al., 2011). The effect of regulation (social or economic) depends on many factors like motive behind any regulations, political condition, and legal environment. Many researcher conduct research on the topic of government regulation at two main extremes; one is normative which focus on the need for regulation and the possible best form of regulation and other is descriptive which focuses on the different forces that effects the regulation like political, economic, bureaucratic and legal.

Generally, firms are affected by regulations, but their impact varies from firm to firm. When firms compliance with regulation, it reduces the number of firms in industry because it is difficult for firms to compliance with government regulation as it increase the cost of production and reduce the profit margins (Pashigian, 1984). Compliance with regulation increases the cost of production which is five times higher for small business then the large one (Crain \& Crain, 2010). Complex regulations are not a good sign for already operating firm as it leads toward reduction in investment, firm growth and firm profits (Alesina et al., 2005; Loayza et al., 2005; Bastos \& Nasir, 2004). Restrictions affect the firm performance (Loayza et al., 2005). Also it is found that strict regulations encourage the corruption, firm does not want that their performance reduces by following the regulations, so that they use illegal actions such as corruption to reduce the effect of regulations. Djankov et al. (2002) found that regulation increases the competition. Price et al., (2011) found that regulations reduce the efficiency and restrict the operations of an option market in Mexico. Alesina et al. (2005) suggest that regulation is a determinant for firm investment. Dawson (2006) reveals that regulatory framework has a significant relationship with firm investment and find that relax regulation can increase the firm investment that enhances the growth of a firm and high productivity. Government regulations reduce 
the capability of firm in the acquisition of funds from the external parties and create uncertainty for firm performance (Khwaja \& Mian, 2005).

The prices of securities directly link with the changes in regulations. Return on investment also changes against amendment in regulatory framework. Extreme regulations have a negative impact on investments, and it reduces the ability of firm to invest in a more expensive but most profitable projects (Suchard, 2009; Hamdouni, 2011). The ability of a firm to acquire funds from outside parties is reduced to greater extent by following the regulations and it results in uncertainty in the performance of the firm (Khwaja \& Mian, 2005). Therefore; there is a significant negative relationship between extensive regulations and firm performance. Regulatory framework is a key factor during the cross-country comparison of performance of companies (Kunt et al., 2008; Lensink et al., 2008; Hasan et al., 2009; Claessens \& Horen, 2012). Further, Lensink et al. (2008), Claessens and Horen (2012) and Chortareas et al. (2013) also studied the impact of country's regulatory framework on the firm performance.

Complex business regulation increases cost of input which ultimately affects the profit of firms (Loayza et al., 2005). Similarly, law and finance literature also suggest that regulations are directly influencing the financial efficiency (Qian \& Strahan, 2007; Laeven \& Majnoni, 2005). Kalyvas and Mamatzakis (2014) document that business regulations are of key important and optimal use of regulation increases economic growth. Dietrich and Hauck (2014) conclude that regulation in banking sector also effect the firm performance. There also exists evidence of impact of regulation on firm performance (Kaplan, Piedra \& Seira, 2011; Bruhn, 2013; Mel, McKenzie \& Woodruff, 2013; Monteiro \& Assunção, 2012). Trade related regulations also affect the cost of firms which ultimately affect the performance of firms (Hoekman \& Nicita, 2011; Chang, Kaltani \& Loayza, 2009; Djankov, Freund \& Pham, 2010; Dreher \& Gassebner, 2013; Freund \& Rocha, 2011; Perez \& Wilson, 2011).

In existing literature, studies such as Giannetti and Jentzsch (2013), Houston et al. (2010), John, Litov and Yeung (2008), Visaria (2009), Gine and Love (2010), Cavalcanti (2010), Toal, Mookherjee and Visaria (2012), Buyukkarabacak and Valev (2012) examined the diverse nature of regulations - regulations on bankruptcy laws, credit market, courts, financial market and investor protections - and empirically conclude that it has an effect on operating firms. Monteiro and Assuncao (2012) and Lawless (2013) conclude that tax regulations affect the financial performance. Literature also agrees that business regulatory framework strongly affect the performance of firms (Amiti \& Khandelwal, 2011; Barseghyan, 2008; Freund \& Bolaky, 2008; Dutz et al., 2011; Djankov, McLiesh \& Ramalho, 2006). Literature advocates that there is a relation between regulations imposed by regulatory authority and performance of firms. Most of the literature skewed towards the regulations in banking sector, tax regulations, trade related regulations, bankruptcy laws, and regulations in financial markets. Further there is no real consensus regarding the impact of regulations on firm performance. Existing literature paid no attention to the effect of regulations one the share prices of one of the most vital sectors in economy i.e. oil and gas sector. This study contributes to literature by investigating the impact of regulatory changes made by oil and gas regulatory authority (OGRA) on share prices in oil and gas sector of Pakistan.

\section{Data Description and Research Methodology}

We use the Bloomberg database to collect the data related to the daily share prices of listed companies in the oil and gas exploration and oil and gas marketing sector in Pakistan stock exchange from year 2002 to 2013. Study uses the KSE-100 index as an equity representative index of Pakistan stock exchange and its historical prices are collected from the data portal of Pakistan stock exchange. The sample of our research includes all the listed firms in the oil and gas sector of Pakistan stock exchange which comprises of 12 companies. We select 13 regulations and related data has been collected from the Pakistan energy books, oil and gas regulatory authority, annual report of companies, ministry of petroleum and natural resources and US energy information administration.

Our selected study period (July 2000 - March 2013) is crucial with respect to intensive variation in international oil prices, and there also exist significant amendment in the Oil Company's advisory council (OCAC) and oil and gas regulatory authority's (OGRA) framework in Pakistan. During this selected time period, Pakistan also observed many 
political uncertainties and up-gradation in the judiciary system of the land. Initially we selected 20 regulatory changes in oil and gas sector of Pakistan from July 2000 to March 2013. Then we short listed and excluded some of the announcement related to oil and gas sector such as proposal to reduce custom duty in February 2008, pricing frequency is changed in June 2012, committee formed by supreme court for oil and gas sector in December 2009 etc. Table 1 shows the date wise selected event for this study. Our selected 13 regulations are primarily related to deregulation of the prices, circulation of OGRA ordinance, privatization of one of the largest oil refineries, and interference of political government and role of Supreme Court in oil and gas sector of Pakistan.

\subsection{Research Methodology}

This research is based on the problem that how regulatory announcement made by oil and gas regulatory authority influences the performance of the company in the oil and gas sector of Pakistan. Existing literature uses two types of methodologies for such type of research problems i.e. use of dummy variables in the least square framework and second is the application of event study methodology (Ryan \& Taffler, 2004; Vithessonthi \& Techarongrojwong, 2012; Stankeviciene \& Akelaitis, 2014). We use both the methodologies in this study.

\section{Table 1}

\section{List of Selected Regulations in Oil and Gas Sector of Pakistan}

\begin{tabular}{|c|c|c|}
\hline Serial & Date & Regulations \\
\hline 1 & 1-Jul-00 & Fuel oil import and price deregulated \\
\hline 2 & 1-Sep-00 & Liquefied petroleum gas (LPG) prices deregulated \\
\hline 3 & 15-Mar-01 & Self-management of freight pool implemented through OCAC \\
\hline 4 & 13-Mar-02 & $\begin{array}{l}\text { The government has approved increase in oil marketing companies' } \\
\text { distribution margin }\end{array}$ \\
\hline 5 & 28-Mar-02 & OGRA ordinance promulgated \\
\hline 6 & 7-Jul-05 & $\begin{array}{l}\text { NRL (second largest refinery) privatized, Attock group emerged successful } \\
\text { bidder }\end{array}$ \\
\hline 7 & 16-Apr-06 & $\begin{array}{l}\text { Function of price fixation transferred to oil and gas regulatory authority } \\
\text { (OGRA) and it is responsible for price notification. }\end{array}$ \\
\hline 8 & 20-Jun-08 & Deemed duty on Aviation fuel and other products removed \\
\hline 9 & 1-Feb-09 & $\begin{array}{l}\text { As per Government directive, OGRA changed the price announcement } \\
\text { frequency from Fortnightly basis to monthly basis }\end{array}$ \\
\hline 10 & 30-Jun-09 & $\begin{array}{l}\text { Government introduced carbon surcharge, replacing petroleum development } \\
\text { levy }\end{array}$ \\
\hline 11 & 24-Nov-09 & SC formed a committee for proposing changes in oil pricing \\
\hline 12 & 15-Sep-12 & HSD prices for refineries and OMCs made uniform \\
\hline 13 & 8-Mar-13 & Deemed duty on diesel to be increased from $7.5 \%$ to $9 \%$ by 2015 \\
\hline
\end{tabular}

Source: Information related to regulation in oil and gas sector in Table 1 is gathered from the Pakistan energy books, oil and gas regulatory authority, ministry of petroleum and natural resources and US energy information administration.

Study uses well-liked event study approach to capture the impact of regulation announcement on the equity prices of listed companies in oil and gas sector of Pakistan stock exchange. Least square regression methodology is used to investigate the impact of regulation announcement on the firm performance in Pakistan. Beside this, we use the sales growth, leverage, liquidity and tangibility as control variables in our estimated regression model. Generally, when the objective of research is to find the relatively short term impact of any event on some dependent variable then least square methodology is preferred but major advantage of standard event study approach is that it gives day-wise and relatively long term response of dependent variable (Sprenger \& Welpe, 2001; Vithessonthi \& Techarongrojwong, 2013; Bernanke \& Kuttner, 2005). Below section discusses the event study methodology.

\subsection{Event Study Methodology}

Modern finance theory assumes that stock prices include all the relevant available information. Therefore, the price of any security is the summation of present value of all expected future stream of cash benefits. On the basis of modern finance theory, it is possible to analyze the stock prices reaction against any event. Figure 4 shows the details of how prices over-react or under react against the announcement of any event. Here ' $-\mathrm{t}$ ', ' 0 ' and ' $+\mathrm{t}$ ' represents the before event time period, event day and after event window, respectively. 


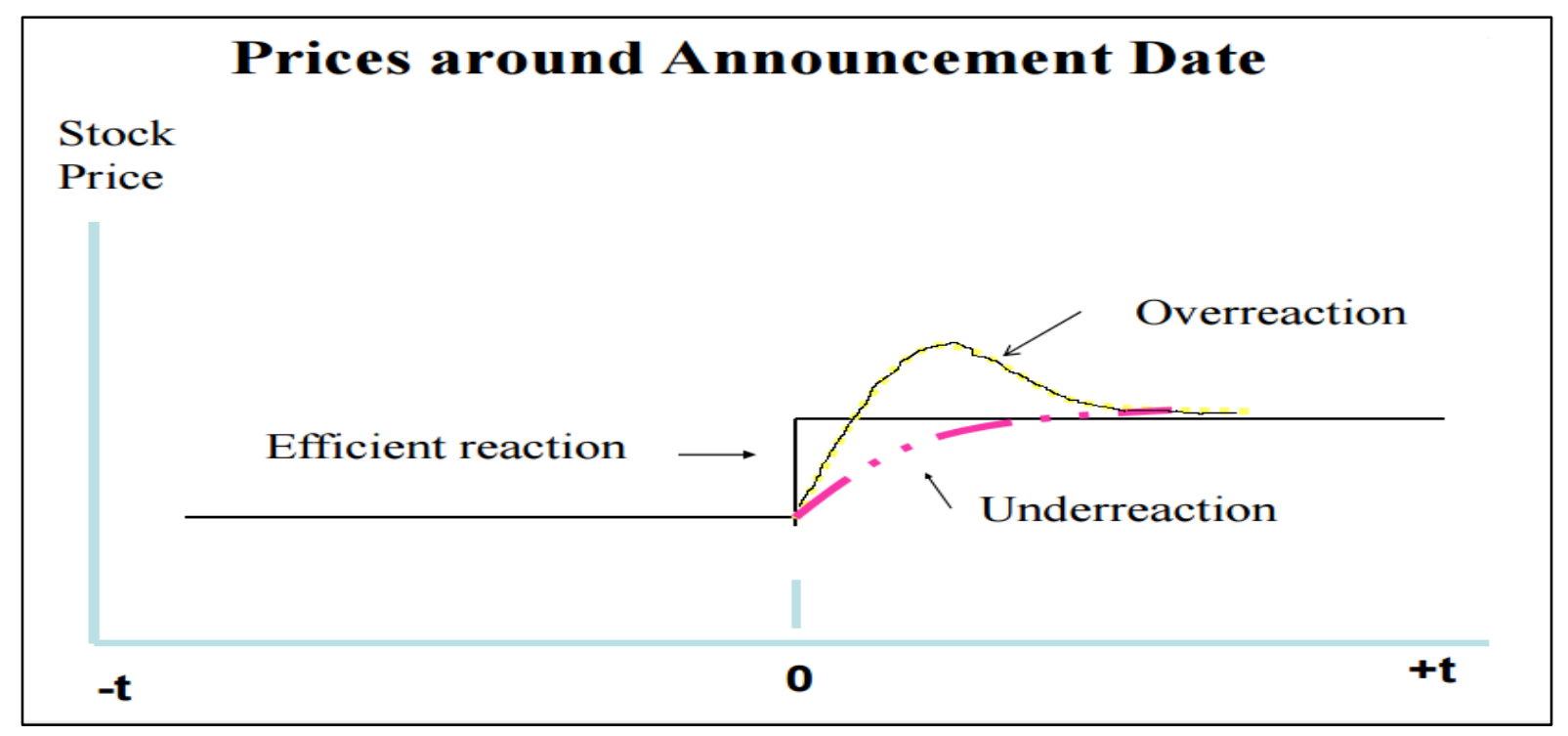

Figure 4: Reaction of Prices round the announcement of events Source: Author's calculations

Event study methodology is a statistical way to look on the reaction of stock prices against any specific event. It is one of the fundamental methodologies in the financial literature and used by catholic of existing literature. Existing literature of twentieth century uses event study approach for varying degree of events, including the corporate events, merger and acquisitions, dividend announcement, tax announcement, economic event, institutional events, calendar events, political events, imposition of new regulations, stock split event, earning announcement and accounting events (Beaver, 1968; MacKinlay, 1997; Kothari \& Warner, 1997; Smith, 1986; Dechow, Sloan, \& Sweeney, 1995; Jensen \& Ruback, 1983; Netter, 1988; Campbell, Lo, \& MacKinlay, 1997; Fama, 1998; Fama, Fisher, Jensen, \& Roll, 1969; Mitchell \& Netter, 1994; Fama, 1991; Barber \& Lyon, 1996; Patell, 1976; Jensen \& Warner, 1988; Campbell \& Wasley, 1996; Brown \& Warner, 1980). Conceptually event study analysis computes the abnormal returns that are attributable to the underlying event. Event study also focus on the behavior of security prices round the studied event.

Recent literature on finance and economics also give healthy evidence in support of the use of event study methodology to investigate the behavior of stock prices against any event. This event may ranges from financial events to non-financial events (Kang \& Kim, 2008; Chuliá et al., 2010; Kothari, 2001; Kothari, Leone \& Wasley, 2005; Farka, 2009; Konrad, 2009; Bernanke \& Kuttner, 2005; Chuliá et al., 2010; Schlumpf et al., 2008; Bredin et al., 2007; Vithessonthi \& Techarongrojwong, 2012; Kuttner, 2005; Lim et al., 2008; Farka, 2009; Rigobon \& Sack, 2004; Bredin et al., 2007; Evrensel \& Kutan, 2007). In line with the existing literature, we use the standard event study methodology in oil and gas sector of Pakistan. We follow the following steps to make empirical analysis under event study approach in Pakistan stock exchange.

1. Identification of relevant events

2. Identification of estimation, event window and post event window

3. Estimation of parameters using the event window

4. Calculate the abnormal returns and cumulative abnormal returns

5. Testing and interpretation of results

First step is the short listing of the relevant events and develop an event profile. As described in the data description part that our selected regulations are primarily related to the deregulation of the prices, circulation of OGRA ordinance, privatization of one of the largest oil refinery, and interference of political government and role of Supreme Court in oil and gas sector of Pakistan. Second step is the determination of appropriate timeline for the event study methodology. Figure 5 shows the timeline for estimation window, event window and post event window for our study.

(Estimation window) (Event window)

$\begin{array}{lllll}\text { T0 } & \text { T1 } & 0 & \text { T2 } & \text { T3 }\end{array}$




\section{Figure 5: Timeline for event study methodology}

The length of estimation window, event window and post event window greatly change in existing literature on event study methodology. It mainly depends upon the nature of events and its likely effect on the stock prices. Since, some events are little planned and information comes in the market before the event, therefore research also uses the preevent window and post-event window. Studies such as Guire, Schneeweis and Naroff (1998), Farka (2009), Rigobon and Sack (2004), Woolridge and Snow (1990), Jacobson (1994) and Williams and Siegel (1997) uses -30 days to +30 days, -50 days to +50 days, -5 days to +100 days, -1 days to +10 days, as length of event window. The event window is the number of days studied before and after the event date. Further, Williams and Siegel (1997) argue that length of event window fully depends upon the nature of event window and therefore it's more subjective than an objective decision. But literature agrees that if expected effect of an event is relatively longer then researcher should use relatively longer pre and post event window. Further it also depends upon the concentration of abnormal performance round the event days. We use 31 days event window that is +15 days pre-event window and -15 days post-event window, including the event day.

\section{Expected Return Vector}

As a third step, we estimate the parameters by using the event window. There are various approaches for estimation of stock returns. It may range from historical average estimation, auto-regressive estimations, auto-regressive integrated moving averages estimations, capital asset pricing model base estimations and multi-factor model-based estimations. We use two types of estimations i.e. historical averages estimation and capital asset pricing model base estimations. As a first step, we compute the continuously computed return for each event of all the listed companies in the oil and gas sector in Pakistan stock exchange by using the following formula of equation (1):

$$
R_{j}=\ln \left(\frac{Z_{t}}{Z_{t-1}}\right) \ldots \ldots
$$

Here, $R_{j}$ denotes the historical continuous compounded return of $\mathrm{j}^{\text {th }}$ stock, $Z_{t}$ and $Z_{t-1}$ represents the current and previous period's market price of shares of selected listed companies at Pakistan stock exchange. Simplest arithmetic mean over the estimation window of each event for all studied firms is estimated by using the following equation (2):

$$
E\left(r_{j}\right)=\frac{1}{K} \sum_{t=1}^{K} R_{j, t} \ldots \ldots \ldots
$$

Here $E\left(r_{j}\right)$ denotes the forecasted return of each event, $R_{j, t}$ denotes the historical continuous compounded return of stock ' $j$ ' and ' $K$ ' shows the length of estimation window. For this study we use 120 days as estimation window i.e. $K=120$ daily returns. Beside the historical estimation technique, we also used the well advocated capital asset pricing model-based estimation for forecasting the expected return vector that is consistent with the study of Kang and Kim (2008) and Schlumpf et al. (2008). It is primarily proposed by William Sharp (1964), Jack Treynor (1961), John Linter (1965) and Jan Mossin (1966). We use the following capital asset pricing model formula of equation (3):

$$
E\left(r_{j}\right)=R_{f}-\beta\left(R_{m}-R_{f}\right)
$$

Where $E\left(r_{j}\right)$ denotes the forecasted return for each event, $R_{m}$ denotes the return of benchmark portfolio and $R_{f}$ denotes the risk-free rate in the country. More specifically, we estimate the following equation (4) for each company ' $\mathrm{j}$ ' and predict the $E\left(r_{j}\right)$ based on estimated coefficient i.e. $\gamma_{0} \& \gamma_{1} R_{\mathrm{mt}}$.

$$
E\left(r_{j}\right)=\alpha_{0}+\gamma_{1} R_{\mathrm{m}, \mathrm{t}}+\varepsilon_{\mathrm{t}} \ldots \ldots
$$

Here, $E\left(r_{j}\right)$ denotes the forecasted returns of each event, $\gamma_{0}$ denotes the constant term, $\gamma_{1}$ measure the sensitivity of company's return towards the market portfolio, $R_{m}$ denotes the return of benchmark portfolio and $\varepsilon_{\mathrm{t}}$ is the error term. We use the KSE-100 as a proxy of the benchmark portfolio in capital asset pricing model.

\subsection{Abnormal Return and Cumulative Abnormal Return}

After the estimation of expected return vector, we compute the abnormal return (AR) and average abnormal return (AAR) as a fourth step of the event study methodology. We estimate the expected return by using the historical 
average estimations as well as by applying the market model. We use the following equation (5) and equation (6) for computation of abnormal returns for each event in the event window.

$$
\begin{gathered}
A R_{j, t}=R_{j, t}-\left(\alpha_{\mathrm{j}}+\gamma_{\mathrm{j}} R_{\mathrm{m}, \mathrm{t}}\right) \\
A R_{j, t}=R_{j, t}-E\left(r_{j, t}\right) \ldots \ldots \ldots(5)
\end{gathered}
$$

Here $A R_{j, t}$ denotes the abnormal returns that is the difference between the actual returns of the firm ' $j$ ' at time ' $t$ ' and the estimated return of firm ' $j$ ' at same time ' $t$ '. $R_{j, t}$ denotes the actual continuous compounded return of the firm ' $j$ ' at ' $t$ ' and computed by using equation (1). Finally, $E\left(r_{j, t}\right)$ denotes the forecasted returns for each event for the firm ' $j$ ' at ' $t$ '. This study also uses historical average estimation for the forecasting of stock return and then we use these forecasted returns for the computation of abnormal return for each event for firm ' $j$ ' at ' $t$ ' by using the equation (6):

$$
\begin{array}{r}
A R_{j, t}=\left(R_{j, t}-\frac{1}{K} \sum_{t=1}^{K} R_{j, t}\right) \\
A R_{j, t}=R_{j, t}-E\left(r_{j, t}\right) \ldots \ldots \ldots(6)
\end{array}
$$

After the computation of abnormal returns $A R_{j, t}$ for consider event against all selected stocks in oil and gas sector of Pakistan, we compute the average abnormal returns (AAR). AAR is very useful to eliminate the firm specific effect by removing the idiosyncrasies. Since we have many events and multiple firms in oil and gas sector of Pakistan, therefore we cannot identify the overall stock market response pattern on the basis abnormal returns. It's better to compute the average abnormal return for each event. We use the following formula of equation (7) for the computation of average abnormal return in oil and gas sector of Pakistan. AAR is the cross-sectional aggregation of the abnormal returns of the entire ' $N$ ' stocks at one point in time.

$$
A A R_{t}=\frac{1}{N} \sum_{t=1}^{N} A R_{j, t} \ldots \ldots \text { (7) }
$$

Where, $A A R_{t}$ denotes the average abnormal returns at time ' $t$ ' and ' $N$ ' shows the number of total stocks in oil and gas sector of Pakistan stock exchange. This study uses the cumulative average abnormal returns (CAAR) to determine the aggregate impact of abnormal returns. It is very useful measure especially when the impact of any event is not explicit on the event date of abnormal returns. Usually in event study most researcher focus on the cumulative average abnormal return (CAAR). CAAR serve as an indicator up to what extent the stock market adjusts new information and try to find that whether the information of change in regulation fully incorporate in the stock prices or not. CAAR can be positive or negative and depends on believe of investors that whether the regulation change the future cash flows. CAAR is also used to gauge the magnitude of an event on the full event window. We use the following equation (8) for the computation of CAAR:

$$
C A A R_{T}=\sum_{t=1}^{T} A A R_{t} \ldots \ldots \ldots
$$

Equation (8) can be written as follow:

$$
C A A R_{t}=C A A R_{t-1}+A A R_{t}
$$

We calculate average abnormal returns (AAR) and cumulative average abnormal return (CAAR) to capture the response of all the selected companies in the oil and gas sector of Pakistan. AAR is the average of abnormal returns of all the companies. Two tests used to check the statistical significance of abnormal return and cumulative abnormal returns i.e. T-AAR and T-CAAR. One uses the time series mean abnormal returns as in Brown and Warner (1980, 1985), and other uses the calendar-time abnormal returns as in Jaffe (1974) and Mandelker (1974). We use the tstatistics using the time-series approach to check the significance. Finally, we employ the t-statistics to comment upon the significance of average abnormal returns and cumulative abnormal returns by using the following equation (9) and equation (10). Here the null hypothesis is that the AAR and CAAR is equal to zero. 


$$
\begin{aligned}
t_{A A R} & =\frac{A A R_{t}}{\sigma_{A A R} / \sqrt{n}} \ldots \ldots \ldots \\
t_{C A A R} & =\frac{C A A R_{t}}{\sigma_{C A A R} / \sqrt{n}} \ldots \ldots \ldots(
\end{aligned}
$$

Here $t_{A A R}$ and $t_{C A A R}$ shows the t-statistic for AAR and CAAR, respectively whereas $\sigma_{A A R}$ denotes the standard deviation of average abnormal return of sample of firms for time ' $t$ '.

\section{Least Square Estimation of Study}

We use two types of methodologies to find out the potential impact of regulatory framework on the firms in oil and gas sector of Pakistan. First is the use the of well-liked event study approach and second is the use of ordinary least square estimations. Study also employs the descriptive statistics to describe the feature of data and draw the correlation matrix to know the strength and direction of relationship among variables of study. Regression analysis is a way to forecast the dependant variable on the basis of set of regressors. It is used to find the impact of independent variables on dependent variable of study. As regulation is an independent variable but it is qualitative in nature and we cannot measure it in terms of numbers. Therefore, the study takes regulation as dummy variable. Dummy variable is one which is used to capture the qualitative nature data in a research. As Schiantarelli et al. (2005); Bourlès (2010); and Scarpetta (2003) put the value of dummy variable 1 if we observe a regulation in any specific year and 0 if there is no change in regulation in oil and gas sector. The list of regulation is provided in Table 1 . Since there are many events happen in any specific year therefore this way of estimation can be considered as relatively weak measure. Therefore, the prime focus of our paper is on the event study methodology. But simultaneously this method allows us to add other set of explanatory variables in the estimated model and we can inference the potential impact of our control variables on the performance of companies in oil and gas sector of Pakistan. We use leverage, liquidity, sale growth and tangibility as control variables while firm performance is considered a dependent variable. The details of these variables are as follow.

\subsection{Specification of Regression Model}

The general form of least square method can be written as follow:

$$
\begin{gathered}
Y \approx f(X, \psi) \\
Y_{t}=\psi+\psi_{1} X_{1 t}+\psi_{2} X_{2 t}+\psi_{3} X_{3 t}+\cdots+\psi_{m} X_{m t}+\varsigma_{t}
\end{gathered}
$$

Here the unknown parameters are denoted by $\psi$ and it may be scalar or vector, $Y$ depicts the regressand, $X$ is the set of regressors and unexplained term is denoted by $\varsigma$.

Since regression analysis is a way to predict the mean value of dependant variable based upon the average value of regressors, therefore it assumes that all the drivers of dependant variables should be included in the regression model. The financial theory criteria also forces the researcher that model should include all the relevant variables based on the financial theory, relevant literature and economic rational. Further the econometric criteria also guide the researchers that it should fulfill all the assumption of the regression model. Primarily, there should be no heteroscedasticy in the model, no auto correlation among the error terms and there should be no multicollinerity in the estimated model. We uses the white test for checking the presence of homoscedasticity, Durbin-Watson test for autocorrelations and correlation matrix for checking the strength of association among regressors.

\subsection{White Test for Heteroscedasticity}

The assumption of heteroscedasticity is central in regression model. Literally it means the data with different (hetero) dispersion (skedasis). With reference to least square estimation it assumes that variance of disturbance term should be fix over period of time i.e. variance of errors should be time invariant. It can be written as $\operatorname{Var}\left(\varsigma_{t}\right)=\sigma^{2} \neq \sigma_{i}^{2}$. If this assumption is violated then the standard error and estimated coefficient are affected and ordinary least square (OLS) is no longer the most efficient estimator. There are various test used to check the heteroscedasticity in the estimated model, it may include the Breusch-Pagan LM test (Breusch \& Pagan, 1979), the Glesjer LM test (Glesjer,1969), the Harvey-Godfrey LM test (Harvey, 1976; Godfrey, 1978), the Park LM test (Park, 1966), the Goldfeld-Quandt test (Goldfeld \& Quandt, 1965) and the White test (White, 1980). We use the White test to check the presence of 
homoscedasticity in our estimated regression model. For this purpose, we adopted the procedure suggested by White (1980). First we estimate the multiple egression equation and estimates the residuals. Then we regress the squares error terms on all the explanatory variables, square of explanatory variables and also included the cross section terms. We test the null hypothesis of homoscedasticity as described in equation (11).

$$
\begin{gathered}
Y_{t}=\psi+\psi_{1} X_{1 t}+\psi_{2} X_{2 t}+\varsigma_{t} \\
\hat{\varsigma}_{j}^{2}=\phi+\phi_{1} X_{1 j}+\phi_{2} X_{2 j}+\phi_{3} X_{1 j}^{2}+\phi_{4} X_{2 j}^{2}+\phi_{5} X_{1 j} X_{2 j}+v_{j} \\
H_{o}=\phi=\phi_{1}=\phi_{2}=\cdots=\phi_{5}=0 \ldots \ldots \ldots \text { (11) }
\end{gathered}
$$

We calculated the $L M=m \cdot R-$ Square statistics. Here ' $\mathrm{m}$ ' is total number of observations. If LM statistics is greater than the critical values, then we reject the null hypothesis and conclude that there is statistical evidence of presence of heteroscedasticity.

Specifically we estimate the following regression equation (12);

$$
R O E=\alpha+\beta_{1} \operatorname{Reg}+\beta_{2} S G+\beta_{3} D E R+\beta_{4} C R+\beta_{5} T a n+e_{t} \ldots \ldots \text { (12) }
$$

Where, ROE denotes the return on equity, REG denotes the dummy for regulation, SG shows the sales growth, DER denotes the debt to equity ratio, $\mathrm{CR}$ is used for current ratio, TAN denotes the tangibility and e denotes the error term in the model.

\subsection{Description of Estimated Model}

This section includes the description of estimated regression model of equation (12). It includes the return on equity, dummy for regulation, sale growth, and debt to equity ratio, current ratio and tangibility.

The agency cost of manager and stockholder pushes the firm towards more debt to minimize free cash available with the manager (Jensen, 1986), bigger debt obligations may act as an inducement for dismissal of project activities that may increase value (Myers, 1977) while proceeding with risky projects (Jensen \& Meckling 1976). Capital gearing is positively related to assets while have negative relation with profit margins (Hung et al (2002). Long-term and total debt ratio has negative impact on performance of SMEs (Joshau, 2007). Leverage works only for a few firms and have negative impact on performance of firm (Madan, 2007). Performance of the firm is negatively influenced by the leverage (Capon, Farley, \& Hoenig, 1990; Kiymaz, 2006). Bigger firms with low growth opportunities and higher insolvency chances utilize long-term debt, they can bear the higher fixed costs of long-term debt whereas, less secure firms have tendency to utilize more long-term debt (Dalber \& Upneja, 2002). The capital structure of firm impacts negatively to the firm performance (Zeitaun \& Tian, 2007). Financail mix of a company is the propotion of debt and equity in the capital of a company. Leverage is the amount of loan uses to finance the firm's assets (Gleason et al., 2000). Leverage is a long-term debt, and firm uses to finance long term assets (Kisgen 2006). Appiadjei (2014) and Sunder and Myers (1999) use debt to equity ratio as a measure of leverage. For this study, debt to equity ratio is used to measure the financial mix of companies in oil and gas sector of Pakistan by using the equation (13);

$$
\text { Debt toEquity ratio }=\frac{\text { Total liabilites }}{\text { Total equity }} \ldots \ldots \ldots \text { (13) }
$$

The term liquidity refers to the firm capacity to meet its short-term obligations and how quickly the assets of firm converted into cash at a fair market price (Scott et al., 1999). Liquidity is an amount of cash that firms kept meeting short term obligations (International Financial Reporting Standards, 2006). Liquidity level of a firm depends upon the account receivable, account payable and inventory conversion cycle policy (Singh, 2004). Firms with high market-tobook ratio experienced high level of liquid assets (Kim, Mauer \& Sherman, 1998). Various studies identify liquidity as a determinant of firm profitability (Islam \& Mili, 2012; Velnampy, 2013; Velnampy \& Pratheepkanth, 2012; Niresh \& Velnampy; 2012). Cash conversion cycle significantly associated with the return on investment of a firm (Dong \& Su, 2010). Delay in cash payments affects the firm performance (Teruel \& Solano, 2007). Firm performance and liquidity have a significant relationship, firm decrease their current liabilities and increase current assets due to the positive and direct relationship between firm performance and liquidity (Almajali et al., 2012). Maina and Muturi (2013) find that liquidity of a firm is positively related to the firm performance. There are several proxies that are used to measure the liquidity of the firm. Dong (2010) and Omondi (2013) used current ratio to measure the liquidity. From equation (14), current ratio is obtained by dividing current assets by current liabilities. 


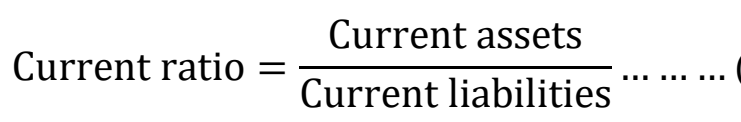

Tangibility is the quantity of assets a company uses to produce goods (Acharya et al., 2006). Tangibility is a number of total tangible assets (Gilson et al., 1990). In the case of assets, tangibility means something that actually and physically exists. There exists a significant positive relationship between tangibility of assets and profitability of firms (Malik, 2011). Tangibility has been measured with fix assets to total assets ratio by Bashir et al. (2013) and found that tangibility has a significant positive relation with firm performance. According to Li (2007), there is no significant relationship and association between tangibility of assets and profitability of the firm. Tangibility has negative and significant relationship with firm's performance (Zeitun \& Tian, 2007). There exists a significant positive relationship between tangibility and the firm performance (Mehari \& Aemiro, 2013; Bashir, Abbas, Manzoor \& Akram, 2013); Chinaemerem \& Anthony, 2012). According to the Trade-off Theory, debt financing is favored by the higher tangibility ratio. Sambasivam and Ayele (2013) find that tangibility has no significant relationship with the profitability of the firm. Mehari and Aemiro (2013) measured tangibility and found that tangibility has a significant positive relationship with firm performance. There are several proxies that are used to measure the tangibility of the firm. Omondi (2013) and Ahmed, Zulfqar \& Usman (2011) use total assets turnover ratio to measure the tangibility. Total assets turnover ratio is obtained by dividing net revenue to average total assets. For this study, total assets turnover ratio used to measure the tangibility of companies in oil and gas sector of Pakistan as describe in equation $(15)$;

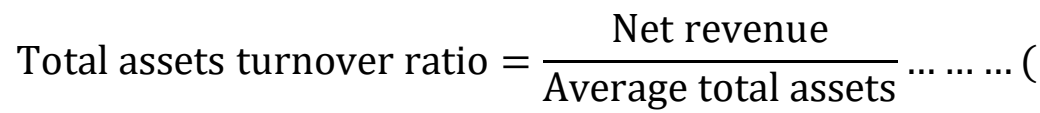

Firm value is affected by the revenue growth (Reilly \& Brown, 2006). Firms can result in good performance when they have capacity for growth. Size of sales affects the profitability to certain amount. (Athanasoglou et al., 2005). Size can verily affect the performance, as the larger firms can leverage their size to maximize the benefits and obtain efficient financial (Mathur \& Kenyon, 1998). It is easier for large firms to reach for cheaper financial resources but Singh and Whittington (1968), and Banz (1981) contradicted to this argument. When the opportunities of growth are given to the firm, it makes the firm to perform much better (Memon et al., 2012) and helps firms to generate profits (Zeitun \& Tian, 2007). Thus, it is concluded that sales growth has a significant positive impact on the firm performance. Sales growth is the known measure of the firm performance (Capon et al., 1990). A change in sales is refers to sales growth. Sinthupundaja and Chiadamrong (2014) and Deloof (2003) used sales growth to measure the change in sale. Sales growth measure by dividing current year sales to previous year sale's minus one. We use the following formula (16) to measure the sale growth;

$$
\text { Change in sales }=\frac{\text { Sale in current year }}{\text { Sales in previous year }}-1
$$

Performance of company can be measure by the book base measure or market base measure. For OLS based estimation, we use book base measure for firm performance. For event study approach, we use the market base measure to check the response of share prices against regulation announcement. Company performance is the rate of change in profitability (Hoskisson et al., 1993). A firm performance is defined as the success of a firm during a year as compared to previous year (Madan, 2007). There are several proxies that are used to measure the performance of the firm. Crain and Crain (2010) and Almajali et al. (2012) use return on equity to measure the firm performance. Return on equity is measure by dividing net income minus preferred equity to common equity. We use return on equity ratio (equation 17) to measure the firm performance of companies in oil and gas sector of Pakistan.

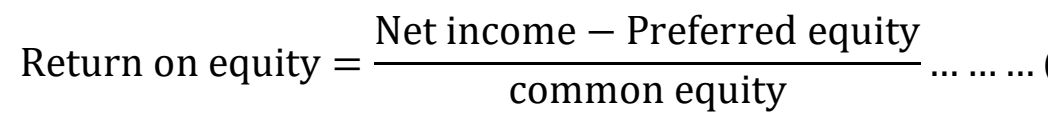

In this paper we employ the event study approach, ordinary least square estimation, correlation analysis and descriptive statics in oil and gas sector of Pakistan stock exchange.

\section{Empirical Findings}

The result in Table 1 show the descriptive statistics applied on the data of the oil and gas sector of Pakistan from a period of 2000 to 2014. A total of 180 observations have been gathered from 12 companies for the analysis. Table 1 shows the mean and standard deviation of the studied variables. Average liquidity of oil and gas sector is 1.91 and the 
standard deviation of liquidity is 1.03 which shows the dispersion from average liquidity. Also, the average value of return on equity is 3.32 with standard deviation 0.48. Similarly, the mean and standard deviation of the entire variables i.e. current ratio, debt to equity ratio, sales growth, return on equity and tangibility are presented at Table 1.

Table 1

Descriptive Statistics

\begin{tabular}{lcc}
\hline \multicolumn{1}{c}{ Variables } & Mean & Standard Deviation \\
\cline { 2 - 3 } Liquidity & 1.9135 & 1.0317 \\
Leverage & 0.3845 & 0.2700 \\
Tangibility & 2.5229 & 1.7265 \\
Sales growth & 0.1582 & 0.1715 \\
Return on equity & 3.3237 & 0.4826 \\
Source: & Author's Calculation &
\end{tabular}

Table 2 shows the results of correlation matrix. Correlation coefficient tells us about the strength and direction of relationship among studied variables. Its values range from -1 to +1 . Table 2 shows the Pearson correlation technique applied on the data of oil and gas sector companies of Pakistan during the period of 2000 to 2014. The correlation coefficient of leverage with return on equity is 0.5130 which indicates that there exists significant substantial degree of relationship between these two variables. The direction of correlation is positive which shows that if leverage ratio changes firm performance change in the same direction. The correlation coefficient of sales growth with return on equity is 0.4614 which indicates that there exists positive and significant moderate degree of relationship between two variables. The correlation coefficient of liquidity and tangibility with return on equity is 0.1166 and 0.1085 which indicates that there exists a low degree of relationship between two variables. The direction of correlation is positive which shows that if liquidity and tangibility change firm performance change in the same direction. From the correlation coefficient it is quite clear that there is no multicollinearity problem on our studied variables.

Table 2

\section{Correlation Matrix}

\begin{tabular}{cccccc}
\hline Variables & ROE & Leverage & Liquidity & Tangibility & Sale Growth \\
\hline ROE & 1 & $.513^{*}$ & $.116^{*}$ & $.108^{* *}$ & $.461^{* *}$ \\
Leverage & $.513^{*}$ & 1 & $.245^{* *}$ & .176 & $.131^{*}$ \\
Liquidity & $.116^{*}$ & $.245^{* *}$ & 1 & .490 & $.030^{*}$ \\
Tangibility & $.108^{* *}$ & .176 & .490 & 1 & $.174^{*}$ \\
Sale Growth & $.461^{* *}$ & $.131^{*}$ & $.030^{*}$ & $.174^{*}$ & 1 \\
\hline
\end{tabular}

* Correlation is significant at the 0.05 level (2-tailed).

**Correlation is significant at the 0.01 level (2-tailed).

Source: Author's Calculation

\section{Regression Analysis}

We investigate the impact of regulations on the firm performance in oil and gas sector of Pakistan stock exchange. Table 3 presents the results of multiple regression analysis of our study. Firm's performance is measured through Return on equity and the independent variable included in the model are sales growth, company's tangibility, company's liquidity, company's leverage and dummy variable for regulations in the oil and gas sector of Pakistan. Results show that value of R-square which indicates $49.99 \%$ of the variance in the dependent variable is explained by our studied independent variables. F-value that is 10.396 shows the overall significance of the estimated regression model. The estimated regression model is also test for auto correlation and heteroscedasticity, and we find no evidence of auto correlation and heteroscedasticity in error terms. The beta value of leverage is 0.8784 . It indicates that a unit increase in leverage will increase the value of firm performance by 0.8784 units. This result is statistically significant because the t-value is 4.788 which are beyond the range of -1.96 to +1.96 at $95 \%$ confidence level thus the regression results of leverage as a determinant of firm's performance are statistically significant. Similarly, sale growth and tangibility have significant impact on firm performance while liquidity has insignificant impact on the performance of firms. Further it can be seen that the beta value of regulation is 2.707 that is also statistically significant thus the regression results of regulation as determinants of firm's performance are statistically significant. 
Therefore, results conclude that regulation in oil and gas sector affects the profitability of firms in Pakistan stock exchange.

Table 3

Regression Analysis

\begin{tabular}{lccc}
\hline \multirow{2}{*}{ Predictors } & \multicolumn{3}{c}{ Outcomes } \\
\cline { 2 - 4 } Regulation & $\mathrm{B}$ & $\mathrm{T}$ & $\mathrm{P}$ \\
\cline { 2 - 4 } Leverage & 2.7077 & 2.5014 & 0.0155 \\
Liquidity & 0.8784 & 4.7881 & 0.0000 \\
Tangibility & 0.0461 & 0.8508 & 0.3987 \\
Sales growth & 0.0569 & 1.7391 & 0.0879 \\
\hline
\end{tabular}

$\mathrm{F}=10.3969, \mathrm{R}$ Square $=0.4999$, Dependent variable $=$ Return on equity.

Source: Author's Calculation

\section{Event Study Methodology}

Event study methodology is used to analyze the impact of regulation announcement on the stock returns in oil and gas sector of Pakistan stock exchange. We selected 13 regulatory changes in oil and gas sector of Pakistan. Table 1 shows the average abnormal return (AAR) and cumulative average abnormal return (CAAR) of event 1 , event 2 and event 3 on 31-day event window i.e. -15 days to +15 days in Pakistan. Pakistani government is continuously looking towards the phased deregulation of oil and gas sector of Pakistan. A number of steps had been taken for this purpose. Our first event is the deregulation of fuel oil imports in July 1, 2000, second event is the deregulation of the liquefied petroleum gas prices in September 1, 2000 and third event is the self-management of freight pool by oil marketing companies in March 15, 2001. AAR uses to eliminate the idiosyncrasies in the computation and CAAR is uses to know the aggregate effect of average abnormal returns.

A minor effect is observed through the event window of event 1 . We find no effect of event 1 on the stock prices in the pre-estimation window. A significant positive effect is observed through AAR on $10^{\text {th }}$ and $15^{\text {th }}$ day and $9^{\text {th }}$ and $15^{\text {th }}$ day through CAAR of post event window. Event 2 has significant impact on stock prices in both the pre-event and post-event window. AAR shows a significant effect of this event on the stock returns on $1^{\text {st }}, 3^{\text {rd }}$ and $13^{\text {th }}$ day of preevent window while this event has significant effect on $3^{\text {rd }}$ day after the announcement of regulation. Further aggregate impact is also observed in the pre-event and post-event window of CAAR.

\section{Table 4}

Average Abnormal Return and Cumulative Average Abnormal Return

\begin{tabular}{ccccccc}
\hline \multirow{2}{*}{$\begin{array}{c}\text { Event } \\
\text { Window }\end{array}$} & \multicolumn{2}{c}{ Event 1} & \multicolumn{2}{c}{ Event 2} & \multicolumn{2}{c}{ Event 3} \\
\cline { 2 - 6 } AAR & CAAR & AAR & CAAR & AAR & CAAR \\
\hline-15 & -0.001 & -0.001 & -0.005 & -0.005 & 0.006 & 0.006 \\
-14 & 0.007 & 0.006 & 0.00 & -0.004 & 0.001 & 0.008 \\
-13 & 0.002 & 0.008 & $0.018^{* *}$ & 0.014 & -0.002 & 0.005 \\
-12 & 0.006 & 0.015 & 0.002 & $0.016^{*}$ & 0.006 & 0.011 \\
-11 & 0.005 & 0.021 & 0.006 & $0.022^{* *}$ & $-0.018^{*} * *$ & -0.006 \\
-10 & 0.002 & 0.023 & -0.009 & 0.013 & 0.002 & -0.004 \\
-9 & -0.009 & 0.014 & 0.002 & $0.015^{*}$ & -0.002 & -0.006 \\
-8 & 0.018 & 0.032 & -0.001 & 0.013 & -0.003 & -0.009 \\
-7 & -0.009 & 0.022 & -0.004 & 0.009 & -0.005 & -0.014 \\
-6 & -0.012 & 0.01 & 0.007 & $0.016^{*}$ & 0.005 & -0.009 \\
-5 & 0.006 & 0.016 & -0.003 & 0.013 & -0.002 & -0.011 \\
-4 & 0.011 & 0.028 & -3.956 & 0.013 & 0.00 & -0.011 \\
-3 & 0.014 & 0.042 & $-0.013 *$ & 0.00 & $-0.011^{*}$ & -0.022 \\
-2 & 0.00 & 0.043 & 0.006 & 0.005 & $-0.013 *$ & -0.035 \\
-1 & 0.01 & 0.053 & $0.013 *$ & $0.019 * *$ & -0.004 & -0.039 \\
0 & -0.003 & 0.049 & 0.00 & $0.023^{* *}$ & 0.005 & -0.034 \\
1 & 0.001 & 0.05 & -0.002 & $0.017 *$ & -0.01 & $-0.044^{*}$
\end{tabular}




$\begin{array}{lcccccc}2 & -0.019 & 0.031 & 0.012 & 0.029 * * * & -0.01 & -0.055^{* *} \\ 3 & -0.011 & 0.019 & -0.019 * * & 0.009 & 0.003 & -0.051^{* *} \\ 4 & -0.003 & 0.016 & -0.001 & 0.008 & 0.004 & -0.047^{*} \\ 5 & 0.005 & 0.022 & -0.003 & 0.005 & 0.001 & -0.046^{*} \\ 6 & 0.014 & 0.037 & -0.012 & -0.006 & 0.00 & -0.046^{*} \\ 7 & 0.013 & 0.05 & 0.00 & -0.007 & -0.015^{* *} & -0.061^{* *} \\ 8 & -0.009 & 0.041 & 0.01 & 0.002 & 0.005 & -0.056^{* *} \\ 9 & 0.017 & 0.059^{*} & 0.00 & 0.002 & 0.00 & -0.055^{* *} \\ 10 & 0.035^{* * *} & 0.094^{* * *} & 0.00 & 0.001 & -0.001 & -0.057^{* *} \\ 11 & 0.012 & 0.106^{* * *} & 0.005 & 0.007 & 0.005 & -0.052^{* *} \\ 12 & 0.00 & 0.106 * * * & 0.002 & 0.009 & -0.004 & -0.057^{* *} \\ 13 & -0.006 & 0.099^{* * *} & -0.004 & 0.005 & 0.006 & -0.050^{* *} \\ 14 & 0.002 & 0.102^{* * *} & 0.007 & 0.013 & -0.004 & -0.055^{* *} \\ 15 & 0.021^{*} & 0.124^{* * *} & 0.007 & 0.020^{* *} & 0.001 & -0.054^{* *}\end{array}$

AAR shows the average abnormal return and cumulative average abnormal returns are represented by CAAR. Further, $*, * * \& * * *$ shows the confidence level at $90 \%, 95 \% \& 99 \%$

Source: Author's Calculation

Event 3 affects the share prices in relatively shorter event window. This event has significant impact on stock prices in both the pre-event and post-event window. AAR shows a significant effect on $2^{\text {nd }}, 3^{\text {rd }}$ and $11^{\text {th }}$ day of pre-event window while this event has significant effect on $7^{\text {th }}$ day after the announcement of regulation. But more rigorous effect of this Self-management of freight pool is observed after the event in the post-event window of CAAR.

Table 5 gives the results of event 3, event 4 and event 5 of our study. It reports the average abnormal return and cumulative average abnormal returns of events. Our third event is the approval of increased distribution margin for oil marketing companies by the government on March 13, 2002, fourth event happen on March 28, 2002 when OGRA ordinance promulgated and fifth event is about the privatization of national refinery limited (NRL) in July 7, 2005. Event 4 has significant impact on stock prices in the pre-event window. AAR shows a significant effect on $6^{\text {th }}, 8^{\text {th }}$ and $15^{\text {th }}$ day of pre-event window. But the approval of increased distribution margin has significant aggregate impact on the stock returns in oil and gas sector of Pakistan in both the pre-event and post-event window of CAAR. The $5^{\text {th }}$ event of our study has significant impact on stock prices in both the pre-event and post-event window under AAR and CAAR. AAR shows a significant effect on $3^{\text {rd }}$ and $9^{\text {th }}$ day of pre-event window while this event has significant effect on $13^{\text {th }}$ day after the announcement of regulation. Oil and gas sector in Pakistan observe a significant change when OGRA ordinance promulgated. Result shows that the effect of this regulation is started on the $9^{\text {th }}$ day in pre-event of CAAR and it continues till the end of post-event window of CAAR. The AAR of $6^{\text {th }}$ event shows that it has significant effect on event day and $3^{\text {rd }}$ day of post-event window while CAAR also shows the significant cumulative effect in post event window. But the effect of privation of NRL is only limited to -1 day to 7 day of the event window of CAAR.

The result of average abnormal returns and cumulative abnormal returns for event 7, event 8 and event 9 are presented at Table 6 . The $7^{\text {th }}$ event of our study is concerning the transfer of responsibility of notification of price fixation to oil and gas regulatory authority in April 16, 2006, $8^{\text {th }}$ event is about the removal of duty of aviation fuel and other products in Pakistan on June 20, 2008 and $9^{\text {th }}$ event is regarding the changes in the policy of announcement of price frequency from fortnightly basis to monthly basis on February 1, 2009. We find the aggregate impact of event 7 started from the $6^{\text {th }}$ day of post-event window to $15^{\text {th }}$ day of post-event window of CAAR while AAR shows the significant effect of this event only on the $12^{\text {th }}$ day of the pre-event window. Event 8 has statistically significant impact on stock prices in the pre-event and post-window. AAR shows a significant effect on $6^{\text {th }}$ and $9^{\text {th }}$ day of preevent window while it also shows significant positive impact on $11^{\text {th }}$ day of post-event window. CAAR clearly shows that removal of duty on aviation fuel and other product has significant on the return of oil and gas sector and reaction starts from 1 day before the announcement and it continues to end of our event window i.e. day 15 of post-event window. We reveal that change in the frequency of announcement of prices in oil and gas sector in Pakistan has significant effect on the returns of listed stocks at Pakistan stock exchange. It is clear from the CAAR of event 9 that there exists aggregate effect of this event in the pre-event window and it even more rigorous effect in the post-event 
window.

Table 5

Average Abnormal Return and Cumulative Average Abnormal Return

\begin{tabular}{|c|c|c|c|c|c|c|}
\hline \multirow{2}{*}{$\begin{array}{c}\text { Event } \\
\text { Window }\end{array}$} & \multicolumn{2}{|c|}{ Event 4} & \multicolumn{2}{|c|}{ Event 5} & \multicolumn{2}{|c|}{ Event 6} \\
\hline & AAR & CAAR & AAR & CAAR & AAR & CAAR \\
\hline-15 & $0.009 * *$ & $0.009^{*}$ & 0.005 & 0.005 & 0.008 & 0.008 \\
\hline-14 & 0.001 & $0.011 *$ & 0.003 & 0.009 & 0.011 & 0.019 \\
\hline-13 & 0.001 & $0.013 * *$ & 0.001 & 0.011 & 0.004 & 0.024 \\
\hline-12 & 0.00 & $0.014 * *$ & 0.006 & 0.017 & -0.003 & 0.02 \\
\hline-11 & 0.00 & $0.014 * *$ & 0.011 & 0.029 & -0.004 & 0.015 \\
\hline-10 & 0.00 & $0.013^{* *}$ & -0.005 & 0.024 & -0.004 & 0.011 \\
\hline-9 & -0.005 & 0.007 & $0.019^{* *}$ & $0.043 *$ & 0.003 & 0.015 \\
\hline-8 & $0.010 * *$ & $0.018 * * *$ & 0.00 & $0.043 *$ & 0.004 & 0.02 \\
\hline-7 & -0.001 & $0.016^{* * *}$ & 0.015 & $0.059 * *$ & 0.00 & 0.021 \\
\hline-6 & $-0.01 * * *$ & 0.001 & 0.007 & $0.066 * * *$ & -0.002 & 0.018 \\
\hline-5 & 0.03 & 0.001 & 0.012 & $0.078 * * *$ & 0.006 & 0.025 \\
\hline-4 & 0.001 & 0.003 & 0.005 & $0.083 * * *$ & 0.002 & 0.027 \\
\hline-3 & 0.006 & 0.009 & $0.022 * *$ & $0.105^{* * *}$ & -0.001 & 0.026 \\
\hline-2 & 0.001 & $0.011^{*}$ & -0.009 & $0.096^{* * *}$ & 0.00 & 0.025 \\
\hline-1 & 0.004 & $0.016 * * *$ & -0.014 & $0.081 * * *$ & 0.005 & $0.031^{*}$ \\
\hline 0 & -0.001 & $0.014 * *$ & -0.015 & $0.066 * * *$ & $0.022 * * *$ & $0.053^{* * *}$ \\
\hline 1 & 0.002 & $0.017 * * *$ & 0.00 & $0.066 * * *$ & 0.01 & $0.063^{* * *}$ \\
\hline 2 & 0.003 & $0.020 * * *$ & -0.003 & $0.062 * *$ & 0.005 & $0.069 * * *$ \\
\hline 3 & 5.134 & $0.020 * * *$ & 0.00 & $0.063^{* *}$ & $-0.014 * *$ & $0.054 * * *$ \\
\hline 4 & -0.003 & $0.017 * * *$ & 0.005 & $0.068 * * *$ & -0.004 & $0.050 * * *$ \\
\hline 5 & -0.002 & $0.014 * *$ & 0.003 & $0.072 * * *$ & -0.004 & $0.045^{* *}$ \\
\hline 6 & 0.002 & $0.017 * * *$ & -0.003 & $0.068 * * *$ & -0.008 & $0.037 * *$ \\
\hline 7 & 0.00 & $0.017 * * *$ & -0.01 & $0.058^{* *}$ & -0.007 & $0.029 *$ \\
\hline 8 & 0.007 & $0.024 * * *$ & -0.004 & $0.054^{* *}$ & -0.006 & 0.023 \\
\hline 9 & -0.001 & $0.023 * * *$ & -0.002 & $0.051 * *$ & -0.002 & 0.021 \\
\hline 10 & -0.004 & $0.019 * * *$ & -0.004 & $0.047^{*}$ & -0.005 & 0.015 \\
\hline 11 & 0.00 & $0.019 * * *$ & -0.002 & $0.044 *$ & -0.002 & 0.013 \\
\hline 12 & 0.00 & $0.019 * * *$ & 0.003 & $0.048^{*}$ & -0.003 & 0.009 \\
\hline 13 & 0.001 & $0.020 * * *$ & $0.025 * * *$ & $0.073 * * *$ & -0.009 & 0.0005 \\
\hline 14 & -0.002 & $0.018 * * *$ & 0.00 & $0.072 * * *$ & -0.004 & -0.003 \\
\hline 15 & 0.001 & $0.020 * * *$ & 0.003 & $0.076 * * *$ & 0.004 & 0.00 \\
\hline
\end{tabular}

AAR shows the average abnormal return and cumulative average abnormal returns are represented by CAAR. Further, $*, * * \& * * *$ shows the confidence level at $90 \%, 95 \%$ \& $99 \%$

Source: Author's Calculation

Table 6

Average Abnormal Return and Cumulative Average Abnormal Return

\begin{tabular}{ccccccc}
\hline \multirow{2}{*}{ Event } & \multicolumn{2}{c}{ Event 7} & \multicolumn{2}{c}{ Event 8 } & \multicolumn{2}{c}{ Event 9 } \\
\cline { 2 - 6 } Window & AAR & CAAR & AAR & CAAR & AAR & CAAR \\
\hline-15 & -0.006 & -0.006 & -0.003 & -0.003 & 0.006 & 0.006 \\
-14 & -0.003 & -0.01 & -0.007 & -0.01 & 0.01 & 0.017 \\
-13 & -0.003 & -0.013 & 0.00 & -0.011 & 0.001 & 0.018 \\
-12 & $0.016^{* *}$ & 0.002 & -0.002 & -0.013 & -0.001 & 0.017 \\
-11 & 0.006 & 0.008 & -0.004 & -0.017 & 0.001 & 0.019 \\
-10 & 0.01 & 0.019 & -0.013 & -0.031 & 0.011 & $0.030^{* *}$
\end{tabular}




\begin{tabular}{|c|c|c|c|c|c|c|}
\hline-9 & 0.00 & 0.02 & $0.017 *$ & -0.014 & 0.002 & $0.032 * *$ \\
\hline-8 & 0.002 & 0.022 & 0.009 & -0.004 & -0.007 & $0.025 * *$ \\
\hline-7 & 0.00 & 0.023 & 0.006 & 0.001 & -0.01 & 0.014 \\
\hline-6 & -0.006 & 0.016 & $-0.021 * *$ & -0.02 & -0.006 & 0.008 \\
\hline-5 & 0.007 & 0.023 & -0.003 & -0.023 & -0.006 & 0.002 \\
\hline-4 & -0.009 & 0.013 & -0.005 & -0.028 & 0.007 & 0.009 \\
\hline-3 & -0.01 & 0.003 & -0.016 & -0.045 & 0.007 & 0.017 \\
\hline-2 & -0.006 & -0.003 & 0.002 & -0.042 & 0.00 & 0.016 \\
\hline-1 & -0.009 & -0.013 & -0.014 & $-0.057 *$ & 0.006 & $0.022 *$ \\
\hline 0 & -0.002 & -0.015 & -0.008 & $-0.065 * *$ & 0.00 & $0.023 *$ \\
\hline 1 & 0.002 & -0.012 & -0.01 & $-0.079 * *$ & -0.009 & 0.013 \\
\hline 2 & -0.01 & -0.023 & -0.006 & $-0.082 * * *$ & 0.01 & $0.024 *$ \\
\hline 3 & -0.003 & -0.026 & -0.004 & $-0.086 * * *$ & 0.008 & $0.033 * * *$ \\
\hline 4 & -0.008 & -0.035 & -0.011 & $-0.098 * * *$ & 0.008 & $0.042 * * *$ \\
\hline 5 & -0.008 & -0.044 & -0.001 & $-0.100 * * *$ & 0.005 & $0.048 * * *$ \\
\hline 6 & -0.011 & $-0.055^{*}$ & 0.014 & $-0.086 * * *$ & -0.005 & $0.042 * * *$ \\
\hline 7 & -0.008 & $-0.063 * *$ & 0.008 & $-0.078 * *$ & -0.01 & $0.033 * *$ \\
\hline 8 & -0.003 & $-0.067 * *$ & 0.001 & $-0.076 * *$ & 0.005 & $0.037 * * *$ \\
\hline 9 & -0.001 & $-0.069 * *$ & 0.008 & $-0.068 * *$ & 0.00 & $0.038 * * *$ \\
\hline 10 & 0.01 & $-0.058^{*}$ & 0.009 & $-0.058 *$ & $0.014 *$ & $0.053 * * *$ \\
\hline 11 & 0.007 & $-0.051^{*}$ & $0.020 *$ & -0.038 & -0.009 & $0.043 * * *$ \\
\hline 12 & 0.00 & $-0.051 *$ & -0.013 & $-0.051 *$ & -0.006 & $0.036 * * *$ \\
\hline 13 & -0.001 & $-0.052 *$ & -0.007 & $-0.058 *$ & -0.012 & $0.023 *$ \\
\hline 14 & 0.00 & $-0.053 *$ & 0.003 & $-0.055^{*}$ & -0.005 & 0.017 \\
\hline 15 & 0.001 & $-0.051 *$ & -0.011 & $-0.066 * *$ & 0.01 & $0.028 * *$ \\
\hline
\end{tabular}

AAR shows the average abnormal return and cumulative average abnormal returns are represented by CAAR. Further, $*$,** \& *** shows the confidence level at $90 \%, 95 \% \& 99 \%$

Source: Author's Calculation

Table 7 give the results of average abnormal returns and cumulative abnormal returns for event 10 , event 11 , event 12 , and event 13 in oil and gas sector of Pakistan. We consider the introduction of carbon surcharge by the government as replacement to petroleum development levy on June 30, 2009 as $10^{\text {th }}$ event of this study. $11^{\text {th }}$ event of our study is regarding the formulation of committee for proposing changes in oil prices by the supreme court on November 24 , 2009 and $12^{\text {th }}$ event is the about the standardization of HSD prices for refineries and OMCs on September 15, 2012. The final event of our study is regarding the increase in duty on diesel on March 8, 2013. The $10^{\text {th }}$ event has significant impact on stock prices in the pre-event and post-window. AAR shows a significant effect on $13^{\text {th }}$ and $14^{\text {th }}$ day of pre-event window while it shows also significant impact on event day and $1^{\text {st }}$ day of post-event window. CAAR also shows the significant cumulative effect in pre-event and post event window.

Table 7

Average Abnormal Return and Cumulative Average Abnormal Return

\begin{tabular}{ccccccccc}
\hline \multirow{2}{*}{ Event } & \multicolumn{2}{c}{ Event 10} & \multicolumn{2}{c}{ Event 11} & \multicolumn{2}{c}{ Event 12} & \multicolumn{2}{c}{ Event 13} \\
\cline { 2 - 8 } Window & AAR & CAAR & AAR & CAAR & AAR & CAAR & AAR & CAAR \\
\hline-15 & 0.017 & 0.017 & 0.001 & 0.001 & 0.004 & 0.004 & 0.008 & 0.008 \\
-14 & $0.065^{* * *}$ & $0.082^{* * * *}$ & $0.010^{* *}$ & 0.011 & 0.008 & 0.013 & 0.001 & 0.01 \\
-13 & $-0.07^{* * *}$ & 0.015 & 0.004 & 0.016 & 0.007 & 0.02 & -0.003 & 0.006 \\
-12 & 0.00 & 0.015 & 3.867 & 0.016 & -0.005 & 0.014 & -0.006 & 8.502 \\
-11 & -0.003 & 0.012 & $0.008^{* *}$ & $0.025^{* *}$ & 0.00 & 0.015 & -0.005 & -0.005 \\
-10 & -0.007 & 0.004 & -0.001 & $0.023^{* *}$ & 0.003 & 0.018 & 0.00 & -0.005 \\
-9 & 0.00 & 0.005 & 0.003 & $0.027^{* * *}$ & 0.003 & 0.022 & -0.006 & -0.012 \\
-8 & 0.001 & 0.007 & -0.006 & $0.021^{* *}$ & 0.002 & 0.025 & 0.0039 & -0.008 \\
-7 & 0.002 & 0.009 & 0.00 & $0.020^{* *}$ & 0.002 & 0.027 & 0.0031 & -0.005 \\
-6 & 0.005 & 0.015 & 0.004 & $0.025^{* *}$ & 0.002 & 0.029 & -0.005 & -0.01 \\
-5 & 0.007 & 0.022 & 0.006 & $0.031^{* * *}$ & $0.020^{* *}$ & $0.050^{* *}$ & 0.007 & -0.002 \\
-4 & 0.002 & 0.025 & -0.002 & $0.028^{* * *}$ & 0.002 & $0.052^{* *}$ & -0.004 & -0.006 \\
-3 & -0.01 & 0.014 & $0.007^{*}$ & $0.035^{* * *}$ & 0.004 & $0.057 * *$ & 0.00 & -0.007 \\
-2 & 0.001 & 0.015 & 0.005 & $0.040^{* * *}$ & 0.00 & $0.056^{* *}$ & 0.015 & 0.008
\end{tabular}




$\begin{array}{ccccccccc}-1 & 0.003 & 0.019 & 0.001 & 0.042 * * * & 0.003 & 0.060 * * & 0.003 & 0.012 \\ 0 & 0.06 * * * & 0.083 * * * & 0.00 & 0.043 * * * & -0.004 & 0.056 * * & -0.003 & 0.009 \\ 1 & -0.06 * * * & 0.019 & 0.00 & 0.044^{* * *} & -0.003 & 0.053 * * & 0.002 & 0.011 \\ 2 & 0.00 & 0.018 & -0.006 & 0.037 * * * & -0.001 & 0.051 * * & 0.002 & 0.013 \\ 3 & -0.003 & 0.015 & 0.005 & 0.042 * * * & -0.003 & 0.047 * * & 0.126 * * * & 0.140 * * * \\ 4 & 0.00 & 0.015 & 0.00 & 0.041 * * * & -0.006 & 0.041 * & -0.14 * * * & -0.001 \\ 5 & 0.004 & 0.02 & 0.00 & 0.041 * * * & -0.005 & 0.035 & 0.121 * * & 0.119 * * * \\ 6 & 0.007 & 0.027 & -0.002 & 0.039 * * * & -0.008 & 0.026 & -0.14 * * * & -0.014 \\ 7 & -0.002 & 0.025 & -0.002 & 0.036 * * * & 0.008 & 0.035 & 0.001 & -0.013 \\ 8 & -0.011 & 0.013 & 0.00 & 0.037 * * * & -0.02 * * * & 0.013 & 0.00 & -0.013 \\ 9 & 0.003 & 0.017 & -0.002 & 0.035 * * * & -0.02 * * * & -0.009 & 0.001 & -0.011 \\ 10 & -0.002 & 0.015 & 0.003 & 0.038 * * * & -0.001 & -0.011 & -0.002 & -0.014 \\ 11 & 0.006 & 0.021 & 0.00 & 0.039 * * * & 0.002 & -0.008 & -0.001 & -0.015 \\ 12 & 0.0116 & 0.033 * & -0.006 & 0.032 * * * & 0.004 & -0.003 & -0.001 & -0.017 \\ 13 & 0.002 & 0.035 * * & 0.003 & 0.035^{* * *} & -0.003 & -0.006 & 0.001 & -0.016 \\ 14 & 0.0024 & 0.038 * * & -0.002 & 0.033 * * * & 0.00 & -0.007 & 0.012 & -0.003 \\ 15 & -0.008 & 0.029 * & -0.001 & 0.032 * * * & 0.00 & -0.006 & -0.001 & -0.005\end{array}$

AAR shows the average abnormal return and cumulative average abnormal returns are represented by CAAR. Further, $*, * * \& * * *$ shows the confidence level at $90 \%, 95 \%$ \& $99 \%$

Source: Author's Calculation

The average abnormal return of $11^{\text {th }}$ event shows the significant effect of this event on the $3^{\text {rd }}, 11^{\text {th }}$ and $14^{\text {th }}$ day of the pre-event window. But the formulation of committee for proposing changes in oil prices by the Supreme Court on November 24, 2009 has statistically significant aggregate impact on the pre-event and post-event window of CAAR in Pakistan. The $12^{\text {th }}$ event has significant impact on stock prices in the pre-event and post-window. AAR shows a significant effect on $5^{\text {th }}$ day of pre-event window while it shows also significant impact on $8^{\text {th }}$ and $9^{\text {th }}$ day of postevent window. CAAR also shows the significant cumulative effect round the event in pre-event and post-event window. The $13^{\text {th }}$ event has significant impact on stock prices in the post-window only of AAR and CAAR. AAR shows a significant effect on $3^{\text {rd }}, 4^{\text {th }}, 5^{\text {th }}$ and $6^{\text {th }}$ day of post-event window. CAAR also shows the significant cumulative effect within the one week in post-event window. Further, we only report the result of capital asset pricing model-based estimation. But these results are also consistent with historical average based estimations. Appendix A includes the event wise graph of average abnormal returns (AAR) in oil and gas sector of Pakistan.

\section{Conclusion}

This study is based on the problem that how regulations made by oil and gas regulatory authority influences the stock prices of the companies in oil and gas sector of Pakistan. Therefore, it is also an attempt to comments on the semistrong form of market efficiency in emerging market. With this motive, we analyses the reflection of regulatory announcement in oil and gas sector of equity market of emerging country. We identify 13 regulatory changes in oil and sector of Pakistan through the year 2000 to 2014. These are primarily related to deregulation of the prices of oil related products, circulation of the OGRA ordinance, and privatization of one of the largest oil refineries, interference of political government and role of Supreme Court in oil and gas sector of Pakistan. Our selected study period is crucial with respect to intensive variation in international oil prices, and there also exist significant amendment in the Oil Company's advisory council and oil and gas regulatory authority's framework in Pakistan. During this selected time period, Pakistan also observed many political uncertainties and up gradation in the Judiciary system of the land. Well-liked event study methodology is used to uncover the impact of regulation announcement on equity prices of oil and gas sector. Beside this, we also capture the effect of regulation announcement on the firm performance by introducing the dummy variable in ordinary least framework. In line with the financial and econometric theory criteria, we use the sales growth, leverage, liquidity and tangibility as control variables. Correlation matrix shows that there is statistically significant association among studied variables. The result of regression analysis shows that regulation has significant impact on the profitability of firms in oil and gas sector of Pakistan. Beside this, leverage, sales growth and tangibility are proving to be significant drivers of firm's performance while liquidity results as insignificant for profitability of firms in Pakistan. 
Pakistani government is continuously looking towards the phased deregulation of oil and gas sector of Pakistan. We use event study methodology to analyze the impact of regulation announcement on the stock returns in oil and gas sector of Pakistan stock exchange. We use the average abnormal return and cumulative average abnormal return on 31-day event window. Results shows that the events related to formulation, functions and responsibilities of oil and gas regulatory authority has statistically significant impact on the stock prices in both the pre-event and post-event window. We observer a rigorous aggregate effect on oil and gas regulatory authority's ordinance promulgated in both the pre-event and post-event window of cumulative average abnormal returns. It shows that it's more a planned event and this event is going to price simultaneously into share prices during the whole event window. The privatization of national refineries limited also has significant impact on the share prices. But the effect of privation of NRL is only limited to -1 day to 7 days of the event window of cumulative average abnormal returns. The formulation of committee for proposing changes in oil prices by the Supreme Court on November 24, 2009 has statistically significant aggregate impact on the pre-event and post-event window of cumulative average abnormal returns in oil and gas sector of Pakistan. We find mixed evidence of response of stock prices of oil and gas companies against the announcement of regulation related to deregulation and changes in the prices of oil and gas products in Pakistan. We find significant aggregate impact of average abnormal returns in post-event windows. Therefore, it is concluded that oil and gas sector of Pakistan stock exchange lacks in semi-strong form of efficiency.

These finding are helpful for managers, decision makers and policy makers in a sense that they should be vigilant about changes in regulations by oil and gas regulatory authority in Pakistan. This research also helps the general public to get to know about the oil and gas sector of Pakistan and how regulatory changes and studied variables affect the performance of firms present in the oil and gas sector. We recommend to the policy makers that the stock prices of oil and gas companies are more sensitive toward the regulatory announcement related to interference of Supreme Court and regulations concerning to the formulation, functions and responsibilities of oil and gas regulatory authority in Pakistan. As future research guidelines, we recommend that research should try to control the effect of confounding event- the effect of other related events must be isolated. Subsequent research should consider the estimation error arises during the forecasting of expected return vector for computing the abnormal return. Further, research should compare the findings of simple abnormal returns with the buy-and-hold abnormal return (BHAR) measure in oil and gas sector of Pakistan stock exchange.

\section{References}

Alesina, A., Ardagna, S., Nicoletti, G., Schiantarelli, F., (2005). Regulation and investment. Journal of the European Economic Association 3 (4),791-825.

Bastos, F., Nasir, J., (2004). Productivity and the Investment Climate: What Matters Most? Policy Research Working Paper No.3335. World Bank.

Bo, H., Huang, Z., Wang, C., (2011). Understanding seasoned equity offerings of Chinese firms. Journal of Banking \& Finance 35,1143-1157.

Bourlès, R., Cette, G., Lopez, J., Mairesse, J., Nicoletti, G., (2010). Do Product Market Regulations in Upstream Sectors Curb Produc-tivity Growth? Panel Data Evidence for OECD Countries. Working Papers No. 791. OECD.

BP Statistical Review of World Energy. (2016). June 2016 annual review. Retrieved from http://www.bp.com/

Brammer, S. J., \& Pavelin, S. (2006). Corporate reputation and social performance: The importance of fit. Journal of Management studies, 43(3), 435-455.

Carton, R.B (2006). Measuring organizational performance: metrics for entrepreneurship and strategic management research: Edward Elgar Publishing.

Ciccone, A., Papaioannou, E., (2007). Red tape and delayed entry. Journal of the European Economic Association 5 (2-3), 444-458.

Cong, R.G., Wei, Y.M., Jiao, J.L., Fan, Y., 2008. Relationships between oil price shocks and stock market: an empirical analysis from China. Energy Policy 36 (9), 3544-3553.

Crain, Nicole V., Crain,W. Mark, (2010). The impact of regulatory costs on small firms. U.S. Small Business Administration, Office of Advocacy, Washington, DC (September).

Dawson, J.W., (2006). Regulation, investment and growth across countries. Cato Journal 26 (3), 489-509.

Djankov, S., LaPorta, R., Lopez-de-Silanes, F., Schleifer, A., (2002). The regulation of entry. Quarterly Journal of Economics 117 (1), 1-37. 
Du, L., Yanan, H., Wei, C., 2010. The relationship between oil price shocks and China's macro-economy: an empirical analysis. Energy Policy 38 (8), 4142-4151.

Evans, DavidS.,(1986). The differential effect of regulation across plant size: comment on Pashigian. Journal of Law and Economics 29(1), 187-200.(April).

Hamdouni, A., (2011). Venture capitalist's monitoring through board membership and the performance of IPO firms: empirical evidence from France. International Research Journal of Finance and Economics 65, 124-133.

Harker, P. T., \& Zenios, S. A. (2000). What drives the performance of financial institutions? Performance of financial institutions: Efficiency, Innovation, Regulation, 3-31.

Holmes, Thomas, (1998). The effect of state policies on the location of manufacturing: evidence from state borders. Journal of Political Economy 106 (4), 667-705.

Jaffe, A., Peterson, S.R., Portney, P.R., Stavins, R.N., (1995). Environmental regulation and the competiveness of US manufacturing: what does the evidence tell us? Journal of Economic Literature 5, 132-163

Jiao, J.L., Gan, H.H., Wei, Y.M., 2012. The impact of oil price shocks on Chinese industries. Energy Sources Part B 7 (4), 348-356.

Khwaja, A.I., Mian, A., (2005). Do lenders favor politically connected firms? Rent provision in an emerging financial market. Quarterly Journal of Economics 120, 1371-1411.

Klapper, L., Laevan, L., Rajan, R., (2006). Business environment and firm entry: evidence from international data. Journal of Financial Economics 82, 591-629.

Loayza, N., Oviedo, A.M., Servén, L., (2005). The Impact of Regulation on Growth and Informality Cross-country Evidence, World Bank Policy Research Working Paper (3623).

Neely, A. (1999). The performance measurement revolution: Why now and what next? International journal of operations \& production management, 19(2), 205-228.

Nkomani, S. (2013). Corporate social responsibility and financial performance: The Johannesburg Stock Exchange top 100. University of Pretoria.

Pashigian,B.Peter, (1984). The effect of environmental regulation on optimal plant size and factor shares. Journal of Law and Economics27(1),1-28. (April).

Price, R.A., Román, F.J., Rountree, B., (2011). The impact of governance reform on performance and transparency. Journal of Financial Economics 99, 76-96.

Stigler, G., (1971). The theory of economic regulation. Bell Journal of Economics and Management Science 2 (1), 322.

Su, M., Zhang, M., Lu, W., Chang, X., Chen, B., Liu, G., Hao, Y. \& Zhang, Y. (2017). ENA-based evaluation of energy supply security: Comparison between the Chinese crude oil and natural gas supply systems. Renewable and Sustainable Energy Reviews, 72, 888-899.

Wei, Y.M.,Wu, G., Fan, Y., Liu, L.C., 2008. Empirical analysis of optimal strategic petroleum reserve in China. Energy Econ. 30 (2), 290-302 
Appendix A: Event wise graph of average abnormal returns (AAR) of study

Figure A1: Average abnormal returns of event 1 to event 6

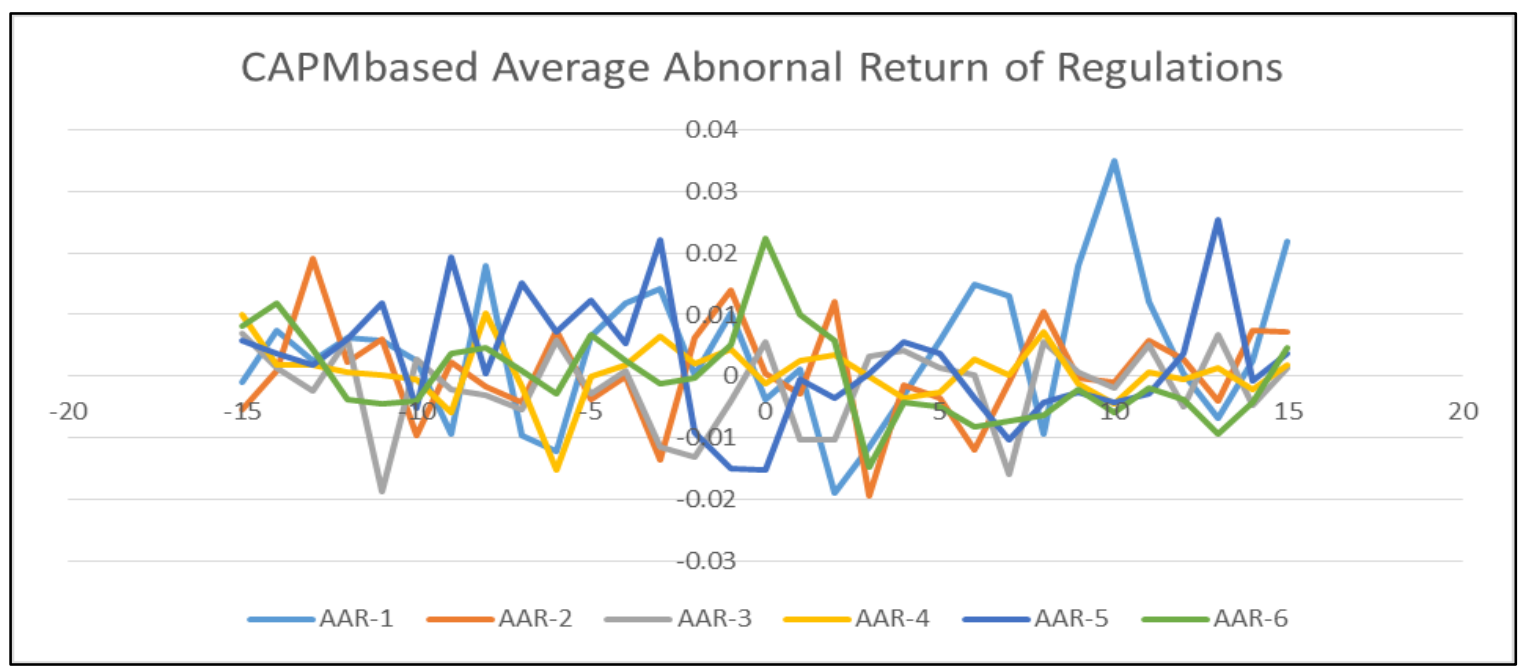

Source: Author's calculation

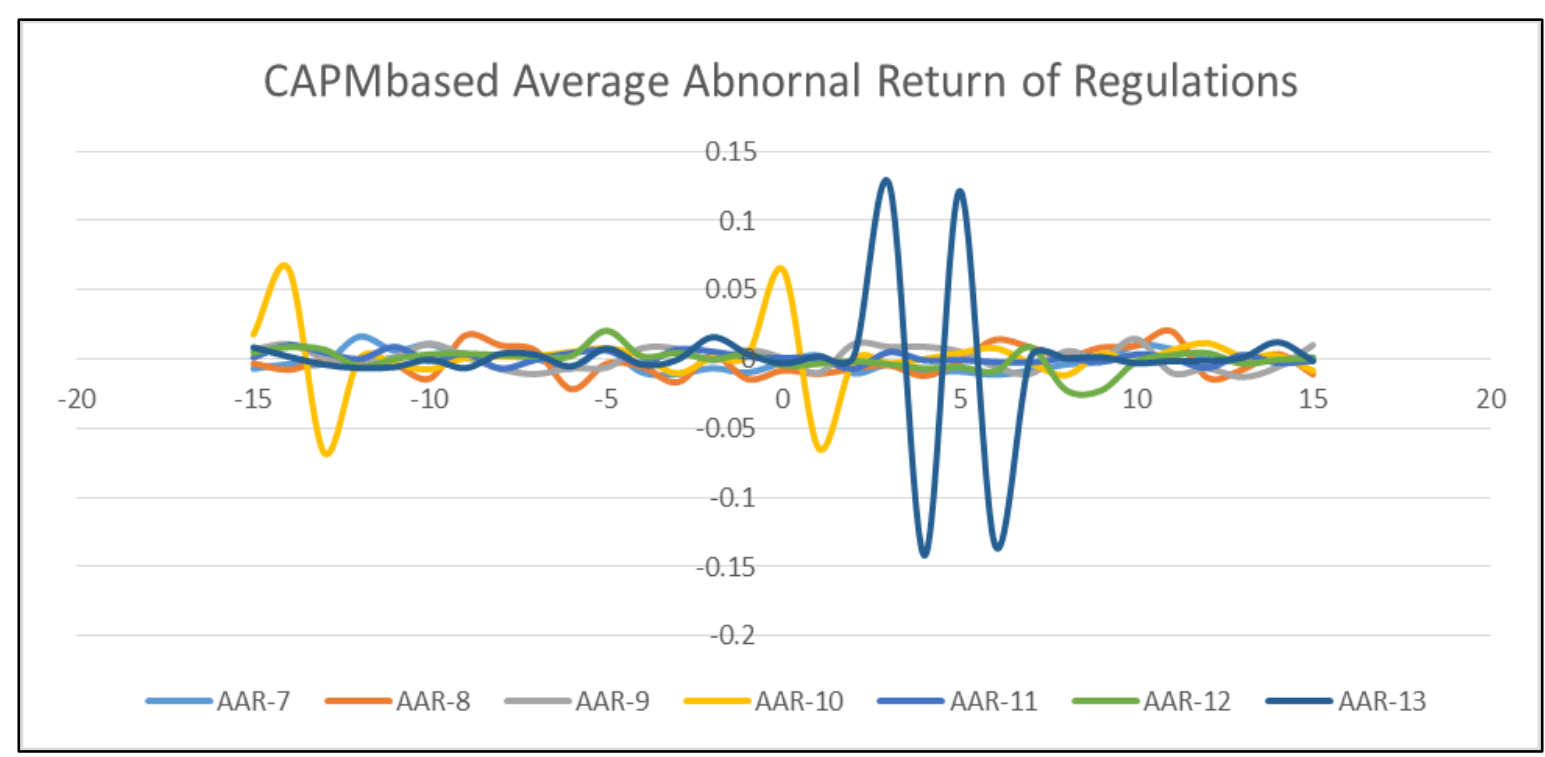

Figure A2: Average abnormal returns of event 7 to event 13

Source: Author's calculation 